\title{
Roger DEGRYSE
}

\section{DE OUDSTE VUURBAKENS VAN DE VLAAMSE KUST EN NABIJGELEGEN NOORDZEEOEVERS (811 - einde 16 de eeuw)}

(DEEL II)

\author{
Overdruk uit \\ Handelingen der Maatschappij voor Geschiedenis en Oudheidkunde te Gent \\ Nieuwe Reeks, dl. XXXVII, 1983
}


DE OUDSTE VUURBAKENS VAN DE VLAAMSE

KUST EN NABIJGELEGEN NOORDZEEOEVERS

(811 - einde 16de eeuw)

(DEEL II) 


\section{DE OUDSTE VUURBAKENS VAN DE VLAAMSE KUST EN NABIJGELEGEN NOORDZEEOEVERS (811 - einde 16 de eeuw)}

(DEEL II)

door

Roger DEGRYSE

\section{De vuurboeten van de Vlaamse kust van Lombardsijde tot Heist}

Te Lombardsijde, aan de rechteroever van de IJzermonding, tegenover de haven van Nieuwpoort, stond een kleine houten ,vierboete", die voor het eerst in 1407 naar aanleiding van haar oprichting of vernieuwing in de oudste van de overgebleven rekeningen van het stadje vermeld wordt ${ }^{130}$. Uit deze stadsrekeningen blijkt verder, dat de Lombardsijdse schepenen niet het direct beheer over dit vuurbaken uitoefenden, maar slechts nu en dan de beherende instantie ervan financieel bijsprongen om zekere uitgaven te helpen dekken ${ }^{131}$. De opbrengst van het ,vierboeteghelt" kwam dan ook ongetwijfeld aan deze inrichtende instelling ten goede. Veel kan dit inkomen evenwel niet bedragen hebben, aangezien de vreemde schippers en stuurlui meestal te Nieuwpoort aan de "vierboeters" aldaar soortgelijk geld betaalden en ze dan niet meer verplicht waren, indien ze de haven van Lombardsijde aandeden, nogmaals zulk een bijdrage te storten. Dit kunnen we afleiden uit een betwisting daarover, die zich in 1418 voordeed. De lieden van Lombardsijde hadden toen vuurboetgeld geëist van een onderhorige van het Brugse Vrije, herkomstig van een , ijde" of strandhaven, waar zich geen vuurbaken bevond. Daar laatstgenoemde reeds elders en dit blijkbaar te Nieuwpoort lichtgeld betaald had, zagen de Lombardsijdse wethouders zich ten slotte verplicht hem niet verder te verontrusten ${ }^{132}$. In de tweede helft van de 15 de eeuw

(130) „Item, den 8sten dach van wedemaend, betaelt Jhan van Brucgdamme, van dat hi hier de vierboete makede, $\mathrm{t}$ elpe sinen costen, $40 \mathrm{~s}$. Item, ter zelver tijt betaelt Jhan Reyvaerde van houte ende van naghelen, dat an de vorseide vierboete ghebesicht was, $12 \mathrm{~s}$. Item, ter zelver tijt betaelt van viere yserine hankers, die ter vorseide vierboete ghebesicht waren, $21 \mathrm{~s}$. Item, ter zelver tijt betaelt ter Nieupoort van drie hoed calx, der mede dat de vorseide vierboete bewoorpen was. Ende voord van haelne ende van bringhene t vorseide calc van der Nieupoort te Lombardye, over al 15 s.". Brussel, ARA, Rekenkamer nr. 35829, stadsrekening over het boekjaar 16 mei 1407 - 6 april 1408, f $2 v^{\circ}-3 r^{\circ}$. De aangerekende munt is in parisis. De volgende stadsrekeningen van Lombardsijde gaan tot 1501 . In de reeks zijn enkele lacunes.

(131) "Item, van costen ghedaen an de vierboete, betaeld 32 s.". Ib., nr. 35836, rek. 1423 - 1424, f $5 \mathrm{v}^{\circ}$. - Van 1408 tot 1423 zwijgen de Lombardsijdse stadsrekeningen over het plaatselijk vuurbaken.

(132) Het Brugse Vrije stuurde op 8 mei 1418 twee afgevaardigden naar Lombardsijde, an buerchmeesters ende scepenen... omme ghetelivreert te hebbene uter vanghenesse Jan fs Michiel Jans, vrylaet, daer ghevanghen ten versouke van der 
zien we de gemeente Lombardsijde jaarlijks de uitgaven betreffende de in de plaatselijke "vierboete" verbrande "gleuy" bekostigen ${ }^{133}$. De gebeurtenissen van het jaar 1489, namelijk de oorlog tussen de aanhangers en de tegenstanders van aartshertog Maximiliaan, beiden door vreemde troepen gesteund, had voor Lombardsijde noodlottige gevolgen. In tegenstelling tot Nieuwpoort, dat onder de kundige leiding van de legendarische burgemeester Jan Turpin aan de aanvallen en belegering door de Fransen, bondgenoten van het opstandige Brugge, kon weerstaan, werd het kleine Lombardsijde gedurende die strijd volledig verwoest. Wegens het vertrek van haar zeelui kwam er dan ook nog vóór 1500 een einde aan het onderhoud en het bestaan van het vuurbaken aldaar ${ }^{134}$. Verder oostwaarts functioneerde dergelijke nachtelijke kustverlichting nog te Oostende, Wenduine, Blankenberge en Heist.

Van de "vierboete" te Oostende wordt voor het eerst in 1367 melding gemaakt. Ze maakte toen al lang deel uit van de keten van vuurbakens, die zich aan de Vlaamse kust bevond, zodat we mogen veronderstellen, dat haar oprichting van vóór 1300 of althans van omstreeks dat jaar kan dagtekenen ${ }^{135}$. In de vijtiendeeuwse Oostendse stadsrekeningen, die voor een groot deel bewaard bleven en tot 1403 opklimmen, is er nu en dan van dit baken, waarvan de beherende instantie niet de gemeente, maar een zelfstandig organisme was, sprake ${ }^{136}$. De „vierboete" bevond zich ten westen van de stad in de duinen nabij de stedelijke watergang of vliet ${ }^{137}$.

wet van Lombardsyde, omme dat de vorseide wet van den vorseiden vrylaet hebben wilde vierboete ghelt, mids dat ghene vierboete en staet ter yde, daer de vorseide vrylaet of vaert, in welke hi wedersechghicht was ende zeide, dat hi noit van zulken ghehoort ne hadde ende noyt ne wiste van ghelike ghegheven ende was, ten versouke van den vorseide ghedeputeerden, costeloos ontsleghen, mids dien, dat hi eldre vierboete ghelt ghaf...". Brugge, RA, fonds Brugse Vrije, nr. 154, rek. 1417- 1418, $\mathrm{f}^{\circ} 62 \mathrm{r}^{\circ}$.

(133) „Item, van gleuye ghehoorboort in t branden ter vierboete, ghehaelt te diversche plaetssen hier binder stede ende in Weesthende, over al t jaer $6 \mathrm{lb}$. $10 \mathrm{~s} . "$. Brussel, ARA, Rekenkamer, nr. 35874, rek. 1462-1463, f $7 \mathrm{r}^{\circ}$, rubriek ,ander uutgheven ende dat van houte ende tuerven... ende van anderen diversschen costen...". - Zie ook de vorige en volgende rekeningen, zelfde rubriek.

(134) Edw. Vlietinck, De Yden van Vlaanderen, van Duinkerke tot Sluis, geschied-en talkundige studie, in de reeks Kath. V1. Hoogeschooluitbreiding, jg. XXXV, nr. 10, verhandeling nr. 347. Antwerpen, 1936, p. 12-14. - K. Loppens, De oude vuurtorens van Lombardsijde, in Biekorf, 43ste jaar. Brugge, 1937, p. 299-301, met een kaartje, waarop de "vierboete" aan de rechteroever van de kreek van Lombardsijde gelokaliseerd staat. In deze studie is er ook sprake van een oudere vuurboet in de duinen nabij Westende, maar daarvan bestaat geen schriftelijke overlevering.

(135) Zie n. 10.

(136) Van deze beherende instantie bleven de rekeningen niet bewaard.

(137) Op 7 mei 1407 stuurde de Oostendse magistraat een afvaardiging naar Zandvoorde bij het bestuur van het ambacht aldaar met de wens „omme ghedolven te hebben den waterganc van den vierboete westwaerd". Brussel, ARA, Rekenkamer, nr. 37242, rek. 1406-1407, rubriek dagvaarden. - Het volgend boekjaar, tijdens een "meentucht", herhaalden de Oostendse wethouders hun wens ",den krync van den "vliete, die leghet bi den vierboete" te zien gedolven worden. Ibidem, nr. 37243, rek. 1407-1408. E. Vlietinck, Het Oude Oostende en zijn driejarige belegering. Oostende, 1897 , p. 34 , voetnoot 5 , en p. 64, voetnoot 3. - Met deze vliet werd heel 
Haar beheer was in de handen van ,vierboetmeesters", bijgestaan door een klerk, die voor de opmaak van de jaarlijkse rekening van de inkomsten en uitgaven instond. Er moet inderdaad een inkomen geweest zijn, bestaande uit de opbrengst van het vuurboetgeld en die werd voor het onderhoud van het baken en de wedde van de ,vierboeter" aangewend. Van deze laatste wordt in 1419 uitdrukkelijk gewag gemaakt en dan nog wel als toenmaals behorende tot de vreemdelingen in de gemeente ${ }^{138}$. De Oostendse schepenen waren elk jaar tegenwoordig bij de ambtsvernieuwing van de ,officiers" of genoemde meesters en klerk van de vuurboet en bij hun eedaflegging, evenals bij het voorlezen van de door hen opgestelde en voorgelegde rekening. Opvallend is dat dit in de eerste helft van de 15 de eeuw gebeurde in het kader van de ambtsvernieuwing van de ,officiers" van de kerk, de armendis en het.gasthuis en van het verhoren van de door die instanties voorgelezen of ingediende rekeningen. Overigens droegen dezen ook de naam meester, namelijk in het meervoud „,kerkmeesters" en ,dischmeesters" — voor het gasthuis traden „voech"den" op - en werden ze eveneens telkens door hun klerk bijgestaan ${ }^{139}$. Misschien is daaruit te besluiten, dat de Oostendse "vierboete" toen een parochiale instelling was naar het voorbeeld van de Brielse ,viereberghen". Het overeenkomstig beheer van deze bakens door vuurboetmeesters zou inderdaad daarvoor kunnen pleiten ${ }^{140}$. Wat er ook van zij, vast staat dat de vuurboet te Oostende niets meer dan een constructie in hout was en dat haar nachtelijk en lichtend vuur vooral voor de vissers gedurende het haringseizoen van groot nut moest zijn. Nadat in de nacht van 14 op 15 september 1422 de ,vierboete” door brand zwaar beschadigd geworden was, begaven de Oostendse wethouders zich onmiddellijk ter plaatse, ten einde de nodige maatregelen voor het laten opruimen van de as en andere verkoolde overblijfselen van het houten gebinte te nemen.

waarschijnlijk de latere havenvliet, die met genoemde watergang in verbinding stond, bedoeld.

(138) „Dit zijn de vreemde lieden... Jan Blate, vierboeter, achterlinc”. Brussel, ARA, Rekenkamer, nr. 37250 , stadsrek. 1419-1420, f $\mathrm{f}^{\circ} 19 \mathrm{r}^{\circ}-23 \mathrm{v}^{\circ}$, zettingslijst van mei 1419. Zie fo $23 \mathrm{v}^{\circ}$. - De Oostendse stadsrekeningen over de boekjaren $1413-1418,1424-1427$ en 1435-1436 ontbreken. Die over de volgende boekjaren zijn bijna voltallig tot 1581 .

(139) ,Item, den 19en dach in wedemaent (1428), zo waren vernieut d officiers van der helegher kerke, van der dissche, van den ghasthuse ende van der vierboete ende haerlieder clerken ende dezelve ghedaen eeden ghelijc dat ghecustumert es... Item, zo waren ghehoort de rekeninghe van de dissche, van den gasthuse ende van der vierboete van deser zelver jaerschaere ende ter zelver tijd, zo was verteirt biden heere, wet, dischmeesters, vierboetmeesters ende voechden van den ghasthuse ende haerlieder clerken... 4 lb.". Ib., nr. 37256, rek. 1428-1429, f $12 \mathrm{v}^{\circ}$. - Zie ook de vorige rek., nr. 37255 , $\mathrm{f}^{\circ} 15 \mathrm{r}^{\circ}$, onder de data 15 aug. en 6 okt. 1427. - Van het verhoor van de rekening van de kerk, samen met de rekeningen van de dis, het gasthuis en de vuurboet wordt melding gemaakt in nr. 37266, rek. 1439-1440, f $15 \mathrm{r}^{\circ}$, en nr. 37267 , rek. $1440-1441, \mathrm{f}^{\circ} 16 \mathrm{r}^{\circ}$, en van hetzelfde verhoor ,byder wet ende kerkemeesters (ende anderen)" in nr. 37269, rek. 1442-1443, fo $12 \mathrm{v}^{\circ}$. - Van de vernieuwing van de officiers en het verhoor van de rekeningen van de dis en de vuurboet door vorig genoemden wordt voor het laatst in nr. 37275, rek. 1448-1449, $\mathrm{f}^{\circ} 10 \mathrm{r}^{\circ}$, gewag gemaakt. - In 1438 was te Oostende in de nieuwe stadskern een nieuwe kerk gebouwd geworden.

(140) Zie n. 189, 192 en 193. 
Tijdens hun onderhandelingen daarover met de ,vierboetmeesters" drongen ze tegelijk bij laatstgenoemden aan snel tot het herstel van het baken over te gaan, gezien de nakende ,harincteilt”. Van enige financiële steun vanwege de stad zelf, blijkt daarbij geen sprake te zijn geweest ${ }^{141}$. Over da eigenlijke wederopbouw van de "vierboete" vernemen we dan ook geen bijzonderheden. We mogen evenwel aanvaarden dat bij deze reconstructie het houten geraamte niet van standplaats veranderd werd en dit ook zo was, nadat in 1446 de stad ten oosten van het gebouw een haven had laten aanleggen. Uit de Oostendse stadsrekeningen van na deze aanleg leren we dat de ,vierboete" zich binnen de nieuwe zeedijk, nabij de "westpoldre" en de ,,westspoye" bevond ${ }^{142}$. Uit dezelfde rekeningen vernemen we over het algemeen niets meer over het toezicht van de schepenen op het beheer van de vuurboet door haar "meesters" of "officiers". Inderdaad alleen in 1467,1468 en 1470 wordt nog van de voorlezing en het verhoor van de vuurboetrekening in aanwezigheid van deze instanties melding gemaakt, wat niet wil zeggen dat die geplogenheid voordien en nadien niet meer plaatsgevonden zou hebben ${ }^{143}$.

We weten niet wat het lot van de ,vierboete" van Oostende is geweest in 1489, toen de stad als inzet van de strijd tussen de Fransen, als bondgenoten van het opstandige Brugge met het Brugse Vrije, en de regent aartshertog Maximiliaan van Oostenrijk door de strijdkrachten van laatstgenoemde verwoest werd met als gevolg de tijdelijke uitwijking van haar zeelui naar Sluis. Eerst van 1491 af kon met de wederopbouw of het herstel van haar beschadigde haven, kaaien, sluizen, dijken en blijkbaar ook "vierboete”, meestal allemaal houten constructies, een aanvang genomen worden. Vanaf 1493 zien we de Oostendse wethouders opnieuw jaarlijks de voorlezing van de vuurboetrekening aanhoren, maar dan niet meer in tegenwoordigheid van de "officiers" van het baken. Daaruit is

(141) ,Item, up den 15 en dach van der voorseide maent (van septembre) (1422), zo trucken borchmeesters ende scepenen ter vierboete, de welke s nachts daer te voren verberrent was, omme te bestedene de asschen ende alle andre dinghen daer ute te werpene ende voort raed en de advis te hebbene met den vierboetmeesters hoe dat men haestelike die vermaken soude ende omme dat noot was ende de harinc teilt voor handen was...". - ,Item, betaelt 6 personen, die nachts wieken als de vierboete berrende, elc 4 s., beloopt 24 s.". Ib., nr. 37253, rek. 1422-1423, fo 14 $\mathrm{r}^{\circ}$ en $16 \mathrm{r}^{\circ}$.

(142) In het kader van de werken tot het intichten van hun haven hadden de Oostendenaars ook besloten tot het maken van een, verlaet", dat zou "ligghen westwaert van der havene tot bi den vierboten". E. Vlietinck, Cartulaire d'Ostende. Antwerpen, 1910 , p. 295, supplement nr. 3, stuk van 11 april 1447. - Met dit „,verlaet" werd blijkbaar de latere ,,westspoye" bedoeld. Op 9 september 1465 greep inderdaad een aanbesteding plaats voor het maken en herstellen van "de dyken jeghen over de vierboete ende by der westspoye". Er is ook sprake van het werk „van den dijc te makene ende te legghene zuud over de vierboete, daer de westpoldre mede bedijct es". Brussel, ARA, Rekenkamer, nr. 37292 , rek. 1465-1466, fo $18 \mathrm{v}^{\circ}$ en $23 \mathrm{r}^{\circ}$. - Zie ook de daaropvolgende rekeningen nrs. 37295, $\mathrm{f}^{\circ} 19 \mathrm{r}^{\circ}$ en $\mathrm{v}^{\circ}$ en 25 $r^{\circ}, 37299, f^{\circ} 25 r^{\circ}, 37300, f^{\circ} 7 r^{\circ}$ en $23 r^{\circ}$, en $37302, f^{\circ} 19 v^{\circ}$.

(143) "Cornelis de Baest (waard), den 9en in april (1467), als de rekeninghe van der vierboete ghehoort was bi der wet ende officiers, ter steden deele $24 \mathrm{~s} . "$. Id., nr. 37294, fo $16 \mathrm{r}^{\circ}$. - Zie ook nr. 37295, rek. 1468-1469, fo $19 \mathrm{r}^{\circ}$, en nr. 37297, rek. $1470-1471, f^{\circ} 16 \mathrm{r}^{\circ}, 8$ juni 1470. 
af te leiden dat de stad Oostende in 1492 of kort voordien het beheer over de ,vierboete" op een of andere wijze overgenomen moet hebben om dit aan een door haar aangestelde klerk toe te vertrouwen, zodat het toch nog steeds zijn autonoom karakter bleef behouden ${ }^{144}$. Voortaan zuiverden de schepenen, telkens het nodig was, het financieel tekort op de jaarlijkse vuurboetrekening aan. Dat de Oostendse ,vierboete” de gemeenschap nu meer geld dan vroeger kostte, kwam ongetwijfeld door haar verbouwing tot een stenen toren, wat vanaf 1492 kan gebeurd zijn. In 1494 blijkt ze maar gedurende zevenendertig nachten, waarschijnlijk tijdens het haringseizoen, in werking te zijn geweest. De stad bekostigde inderdaad voor deze tijdsduur de wedde van de ,vierboeter", berekend op 5 schellingen parisis per nacht, of in het geheel 9 pond 5 schellingen ${ }^{145}$. Ze betaalde in 1497 en 1502 de onkosten voor de uitvoering van metselwerk aan de "vierboete" en ze verleende in 1498 bovendien aan de ,vierboeter" voor zijn arbeid een bijkomende vergoeding ten bedrage van 24 schellingen parisis ${ }^{146}$. Ze vereffende toen tevens een reeks achterstallige schulden onder de vorm van tekorten in de vuurboetrekeningen van 1496 tot en met $1501{ }^{147}$. Vanaf 1506 zuiverde ze voorgoed de tekorten in de door de klerk van het vuurbaken voorgelegde rekeningen aan door de globale vereffening ervan, maar dan alleen telkens voor het in aanmerking genomen afgelopen boekjaar. In de Oostendse stadsrekeningen vinden we dan ook niet elk jaar zulk een aanzuivering aangetekend en dus evenmin telkens de naam van de rekenplichtige klerk van de ,vierboete" vermeld. Voor zover we kunnen nagaan was laatstgenoemde tevens ontvanger van het vuurboetgeld en bleef hij soms of zelfs dikwijls verschillende opeenvolgende jaren in dienst ${ }^{148}$.

(144) „Vertheert den letsten in decembre (1493), als de rekeninghe van der vierboete ghehoort was, 3 lb. 16 s.". Ib., nr. 37316, rek. 1493-1494, fo $23 \mathrm{r}^{\circ}$. „Vertheert den $11 \mathrm{en}$ in novembre (1494) ... als de rekeninghe van der vierboete ghehouden was, 4 lb. 2 s.". Nr. 37317, rek. 1494-1495, fo 20 r $^{\circ}$. Zie ook nr. 37318, rek. 1495-1496, fo $22 \mathrm{r}^{\circ}$, zonder datum. - ,Vertheert den 17en in ougst (1498)... als de rekeninghe van der vierboeten ghehoort was, 3 lb. 13 s.". Nr. 37321, rek. $1498-1499, \mathrm{f}^{\circ} 20 \mathrm{r}^{\circ}$.

(145) „Betaelt Adriaen Maech, vierboetere, van de vierboete bewaert $\mathrm{t}$ hebbene 37 nachten, te 5 s. par. elken nacht, comt 9 lb. 5 s.". Ib., nr. 37317, rek. 1494$1495, f^{\circ} 21 \mathrm{v}^{\circ}$.

(146) „Betaelt Cornelis de Wroede, maetsenare, van dat hij maetste an de vierboete, 3 lb. 12 s.”. Ib., nr. 37320, rek. 1497-1498, f $\mathrm{f}^{\circ} 23 \mathrm{r}^{\circ}$. - "Betaelt Adriaen Vinckedey, vierboetere ter cause van zijn aerbeide, 24 s.". Ib., nr. 37321, rek. $1498-1499, f^{\circ} 25 r^{\circ}$. - Drie metselaars werden ,betaelt ... van ghemetst te hebbene de vierboeten" gedurende drie dagen, $9 \mathrm{lb}$. par. Een handlanger ontving $36 \mathrm{~s}$. par. Ook werden „,22 Vransche barderkins verorboort in de zelve vierboete” naast kalk, zand en stenen. Ib., nr. 37325, rek. 1502-1503, fo $28 \mathrm{v}^{\circ}$.

(147) „Betaelt Michiel Victorsseune Heyns, als clerc van der vierboete, van zekere resten, die men hem $\mathrm{t}$ achtere was ter cause van der zelver vierboete, $51 \mathrm{lb} .16 \mathrm{~s}$. 9 d.". Ib. nr. 37320, rek. 1497-1498, f $23 \mathrm{r}^{\circ}$. - „Betaelt Michiel Victoorsseune Heyns, als clerc $t$ anderen tyden ghezijn hebbende van der vierboete, te wetene de anno 97 ende 98, van meer huut ghegheven dan ontfaen, $74 \mathrm{lb} .16$ s. par., ende Malin Toors, als clerc van de jaren 1499, 1500 ende 1500 een, ooc van meer uutghegheven dan ontfaen $81 \mathrm{lb} .1 \mathrm{~s}$. par., daer of de rekeninghe ghepasseert es voor de wet. Comt t samen 155 lb. 17 s. par.". Nr. 37325, rek. 1502-1503, fo 28 v $^{\circ}$.

(148) „Betaelt Jacob fs Cornelis Jacobs, clerc van der vierboete, van dat men 
In 1507 beroemden de Oostendenaars er zich op het mooiste nachtelijk vuur van de Vlaamse kust te bezitten en tot diens werking en onderhoud ieder jaar financieel heel wat meer dan wat elders het geval was te moeten bijdragen ${ }^{149}$. Dit had blijkbaar ook te maken met de ligging van de toren op of achter de oude zeedijk in de hoge duinen, die steeds door zeeirruptie bedreigd werden ${ }^{150}$. In de ,vierboete" zelf, waarvan geen duidelijke afbeelding bewaard gebleven is, werd, zoals in de andere soortgelijke Vlaamse bakens, 's nachts riet gestookt, maar veel daarover vernemen we niet, evenmin als over de aankoop van die brandstof ${ }^{151}$. Het tekort, dat nu en dan of zelfs verschillende jaren na elkaar in de jaarlijkse vuurboetrekening voortkwam, was uiteraard het gevolg van een onevenwicht in de balans van inkomsten en uitgaven van de betrokken instelling. Deze tekorten waren lange tijd eerder miniem te noemen, aangezien ze zelden de 40 pond parisis overschreden, nogal veel rond de 25 pond lagen en meer dan eens zelfs minder dan 10 pond bedroegen. Er waren ongetwijfeld dan ook jaren, waarin de vuurboetrekening in evenwicht was of met een gunstig saldo kon afgesloten worden ${ }^{152}$. Niettemin drong een betere balans zich voor de andere jaren op. Wellicht was het

hem $t$ achter was ter cause van der vierboete, 46 lb. 10 s. 6 d.". Ib., nr. 37329, rek. 1506-1507, fo $39 \mathrm{r}^{\circ}$. Zie ook nr. 37330, rek. 1507-1508, fo $30 \mathrm{r}^{\circ}$, en nr. 37332, rek. 1509-1510, fo 28 r ${ }^{\circ}$. , ,Betaelt Jacop Corneliszeune Jacops, clerc van der vierboete, van dat hy meer uute ghegheven heeft dan ontfanghen van der zelver vierboete 9 lb. 11 s. 10 d. par.". Nr. 37333, rek. 1510-1511, fo 43 v. Genoemde klerk was dus minstens vijf jaar als dusdanig in dienst geweest.

(149) De Oostendenaars hadden toen geklaagd over de grote uitgaven die ze te dragen hadden, waaronder die besteed, , a lentretenement du feu de nuyt, baillant signe et cognoissance en la mer, qu ilz font au long de 1 an a leurs grans fraiz, plus beau que nul aultre lieu de tout... (le) pays de Flandres...". E. Vlietinck, Cartulaire, p. 118-121, nr. 34, koninklijk oktrooi van 12 juli 1507 aangaande de financiering van de herstellingen aan de dijken te Oostende. Zie p. 119.

(150) In de tekst van een akkoord tussen de wet van het Brugse Vrije en die van Oostende in verband met het aanleggen van een nieuwe sluis lezen we: ,item, zullen (ze) noch maken ende repareeren den dyc naest der zee, streckende voorby de vierboete tot an de hoghe dunen, alzo verre als zy dien van ouden tyden onderhouden hebben ende noch t onderhouden...". Ib., p. 123-128, nr. 36, stuk van 9 okt. 1517. - Een zekere Rycke Driepondt ontving in 1537 van de stad, in minderinghe ter cause dat men hem sculdich es over de eerde ghehaelt uut zynen lande, ghenaemt t Hooghe Stic, ligghende by der vierboẹte", 12 pond. Brussel, ARA, Rekenkamer, nr. 37360, rek. 1537-1538, fo $35 \mathrm{v}^{\circ}$.

(151) In 1518 betaalde de stad 5 pond par. aan Lauwers Zeghers, ,ter cause dat $t$ riet van der voornoemde vierboete in zijn schuere zekeren langhen tyt gheleghen" had, en dit ,naer appointement by der wet jeghens hem ghemaect". Ib., nr. 37341, rek. 1518-1519, f f $^{\circ} 89 \mathrm{r}^{\circ}$. - Voor een rudimentaire of conventionele afbeelding van de Oostendse, ,vierboete", zie de kaarten vermeld in nr. 25 en 26.

(152) Brussel, ARA, Rekenkamer nr. 37337, rek. 1514-1515; nr. 37339, rek. 1516-1517; nr. 37341-37343, rek. 1518-1521; nr. 37350-37354, rek. 1527-1532; nr. 37356-37357, rek. 1533-1535; nr. 36360, rek. 1537-1538; nr. 37362-37364, rek. 1539-1541 ; nr. 37365, rek. 1542-1543 ; nr. 37367-37372, rek. 1544-1550 ; nr. 37374, rek. 1551-1552 en nr. 37383, rek. 1560-1561, telkens onder de rubriek, ander uutgheven van diversche costen". Op te merken is dat de vereffening van het tekort op de vuurboetrekening meestal betrekking had op het jaar, dat het boekjaar van de Oostendse stadsrekening voorafging. Een periode van batig saldo in de vuurboetrekeningen blijken de jaren 1551 tot 1558 geweest te zijn. 


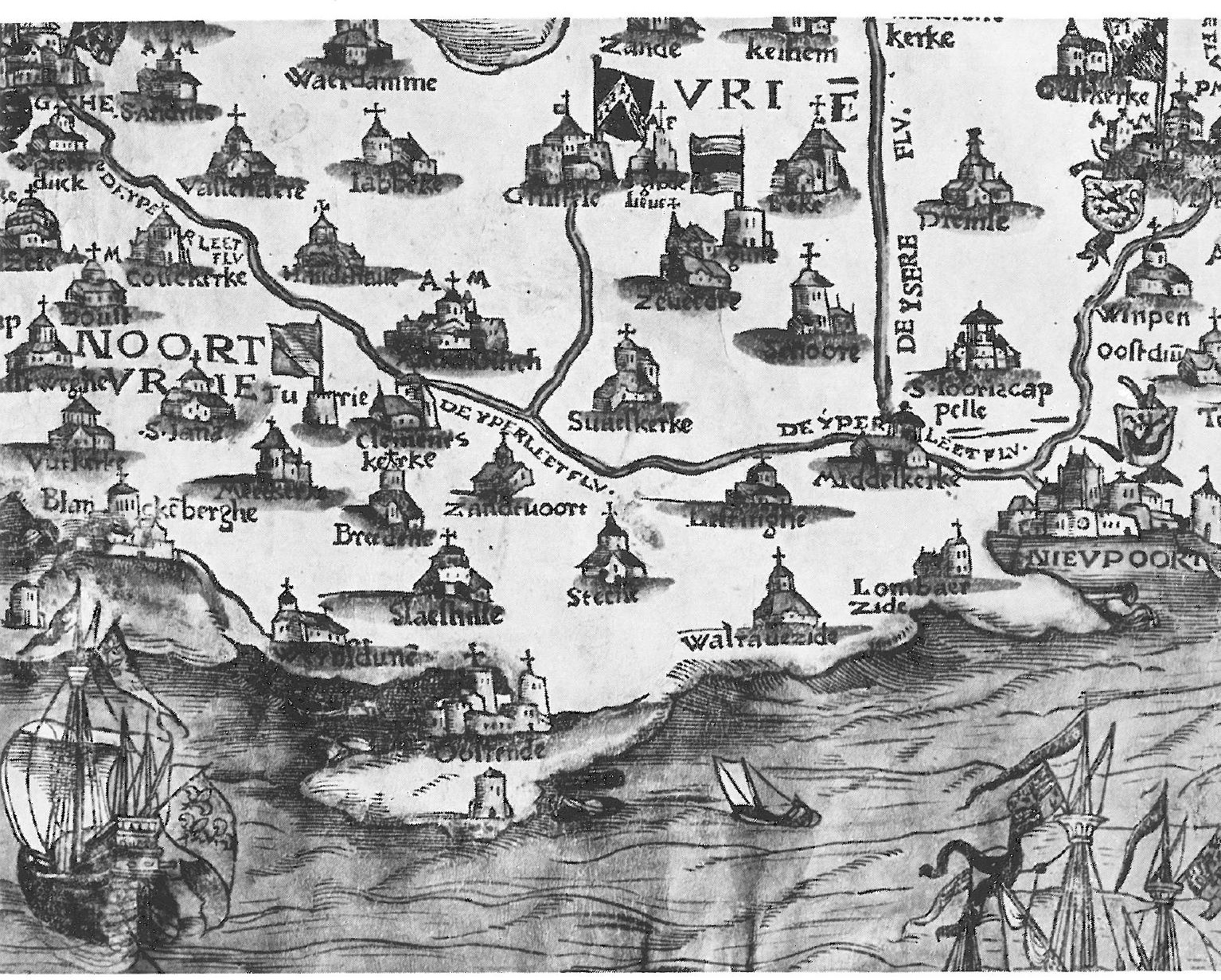

Detail uit de oudste gedrukte kaart van het graafschap Vlaanderen door Pieter van der Beke, van 1538. Houtsnede bewaard in het Germanisches Nationalmuseum te Nuremberg. Hier de kuststrook tussen Blankenberge en Nieuwpoort met de lokalisatie van de aldaar gelegen steden, dorpen, kerken en „vierboetes”. Let op de ligging van de ,vierboèes" van Blankenberge en Oostende, respectievelijk telkens op overgebleven gedeelten van de vroegere meer vooruitgeschoven kust. 


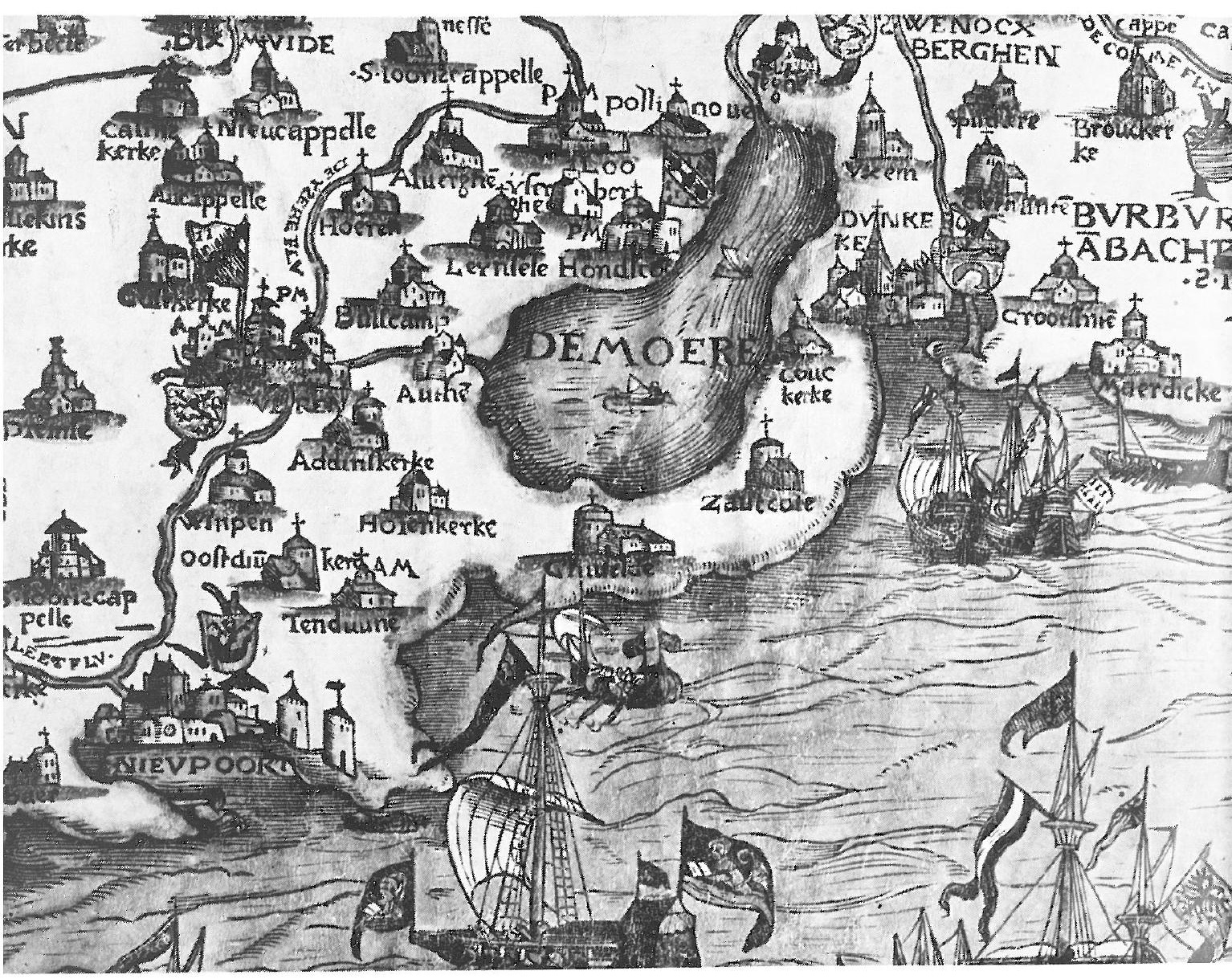

Detail uit de kaart van het graafschap Vlaanderen door Pieter van der Beke van 1538. Hier de kuststrook tussen Nieuwpoort en Mardijk (Mardyck, dep. du Nord) met de lokalisatie van de twee Nieuwpoortse, vierboetes" langs de linkeroever van de brede IJzermonding. Ook een van de twee vuurboeten, staande binnen de wallen van de stad Duinkerke, links van Sint-Elooikerk, is er op te zien en wel met boven haar platform een zwarte rookwolk 
met het oog op deze verbetering dat de Oostendse wethouders in 1540 de stadspensionaris naar Nieuwpoort en Duinkerke zonden om aldaar informatie over de voet, waarop er het vuurboet- en ballastrecht geheven werd, in te winnen ${ }^{153}$. Of dit door een aanpassing van genoemde heffing te Oostende gevolgd werd, vernemen we niet. Zeker is dat van 1541 tot en met 1550, met uitzondering van het jaar 1549, het tekort in de vuurboetrekening zich nu jaarlijks voordeed. Daarna evenwel moeten we tot 1559 wachten om er opnieuw een nadelig saldo in aan te treffen, maar dan een van slechts 7 pond 13 schellingen parisis ${ }^{154}$. Voor het overige blijken de vuurboetrekeningen over de periode lopende van 1551 tot en met 1560 grotendeels in evenwicht te zijn geweest. Een werkelijk hoog oplopend tekort in zulk een rekening deed zich voor het eerst in 1561 voor, vermits het er een was van 189 pond 14 schellingen parisis, wat het gevolg was van de duurte van de voor de vuurboet aangekochte hoeveelheden glui. Het jaar nadien bedroeg het nadelig saldo in de vuurboetrekening 110 pond 4 schellingen parisis ${ }^{155}$. Hoeveel in 1563 het tekort in de rekening van de vuurboet bedroeg, vernemen we niet, maar het moet nogmaals een voor die instelling groot bedrag geweest zijn. In 1564 greep de Oostendse magistraat dan ook in. Daar de stad voor het „Crammen" of versterken van de plaatselijke dijken met rieten matten elk jaar zeer veel glui aan te schaffen had, waarvan de overschotten voor het stoken van de nachtelijke vuren in de ,vierboete" gebruikt konden worden, besloten de schepenen voortaan, ten einde de kostprijs van de aan te kopen grondstof zoveel mogelijk te drukken, zelf al het voor beide doeleinden benodigde riet, na aankoop ervan, te leveren. Het ambt van ontvanger van de vuurboet werd daarom gevoegd bij dit van de tresorier of stadsklerk belast met de boekhouding van de stedelijke financiën en de opstelling van de stadsrekening, die jaarlijks eind maart afgesloten diende te worden. Genoemde klerk mocht de hem aldus opgelegde bijkomende opdracht, waarvoor hij overigens een vergoeding ten bedrage van 12 pond parisis 's jaars zou opstrijken, niet weigeren ${ }^{156}$. De schepe-

(153) „Den vyfsten in maerte 1539 (maart 1540 n.s.), so was ghedeputeert Jan du Moullin, pencionnaris, te reysen ter Nieupoort ende Dunckercke, omme te wetene wat recht dat men aldaer exigierde ter cause van der vierboete ende ballaste ... Betaelt den greffier van Dunckerke voor een acte ende diverssche extraicten ter cause voorscreven 26 s.". Ib., nr. 37362, fo $50 \mathrm{v}^{\circ}$. - Voor het ballast- en vuurboetrecht te Duinkerke, zie n. 79.

(154) De klerk van de ,vierboete" was toen Jan de Wulf. Ib., nr. 37383, rek. 1560-1561, fo $50 \mathrm{r}^{\circ}$. - Zie n. 152. - Berekend in groten bedroeg het genoemde tekort 12 s. 9 d.

(155) De stad betaalde "Cornelis Ververe, als clerk ende ontfangher van der vierboete, ter cause dat hy, by slote van rekeninghe by der wet ghedaen, te boven es meer verschoten hebbende dan ontfaen gheduerende den tyt van zynder clergie ende ghecommen zynde in de stede van Jan de Wulf, de somme van, midts de groote dierste van der gleye, $t$ welcke $t$ incommen van dien nyet mochte vulstringhen... vichtien ponden 16 s. twee penninghen gr., valent 189 lb. 14 s.". Ib., nr. 37385, rek. 1562-1563, f ${ }^{\circ} 65 \mathrm{r}^{\circ}$. - "Betaelt Cornelis Ververe... 9 lb. 3 s. 8 d. gr., comt 110 lb. 4 s. par.", Nr. 37385, rek. 1563-1564, fo $52 \mathrm{v}^{\circ}$.

(156) „Den voornoemde tresorier (Ryckaert Maes), als cletcq ende ghecommitteert by die van der wedt ten ontfanghe ende administratie van de vierboete deser stede ende omme $t$ meeste oirboor ende prouffyt van diere ... hoe wel dat men daertoe 
nen stelden tot bestrijding van de uitgaven voor het onderhoud van de „,vierboete" een jaarlijkse heffing in op de netten, die tijdens de „haryncteelt", telkens vanaf september, door de stuurlui op hun vaartuigen voor de visvangst medegevoerd werden, maar die door de visserswaarden of reders te vereffenen was. De opbrengst van het nieuw vuurboetgeld, waarvan het tarief één grote, d.i. een schelling parisis, per net bedroeg, te betalen op kerstdag, vinden we, met specificatie van het aantal netten per betrokken waard, van het boekjaar 1564-1565 af, in de stadsrekeningen opgetekend. Daar het aantal door de stuurlui medegenomen netten, bijeengevoegd in vleten, in normale omstandigheden vrij talrijk kon zijn, verzekerde de inning van genoemde heffing de stad aanvankelijk een inkomen berekend op de kosten, die ze voortaan voor de instandhouding van haar vuurbaken en diens nachtelijk vuur te dragen had. Ze bracht inderdaad in normale omstandigheden jaarlijks zowat 100 pond parisis op, betaald door ongeveer 36 waarden voor een totaal van rond de 2000 netten ${ }^{157}$. Met uitzondering van de jaarwedde van de ,bediender van de voerboete" of ,vierboeter", ten bedrage van 36 pond parisis, worden de uitgaven voor het onderhoud van de vuurboet en de aankoop van glui voor haar vuurhaard in de Oostendse stadsrekeningen niet gespecificeerd, alhoewel het de gemeente was, die ze voortaan volledig bekostigde ${ }^{158}$. Blijkbaar werden ze door de stadsklerk gerekend bij de globale onkosten voor het onderhoud van de haven, dijken, kaaien, sluizen of stadsgebou-

een particulier persoon voor clercq pleecht te creeren ende nemen, nyetmin de voornoemden van der wedt, up als regardt ghenomen, metgaders oock de groote tachterhede van de voornoemde vierboete, die de stede jaerlicx suppleeren moet $t$ haren laste, hebben, by advyse ende over een draghende met elc andren, de zelve vierboete teenegader over ghenomen ende $t$ clercschip van dien van nu voorts gheapplicquiert and $t$ officie van den tresorier van der stede metten gaigen van diere, als van $20 \mathrm{~s}$. gr. tsiaers, ende ... dat de ghonne, die tresorier ghecreert wordt, zal ghehouden zyn $\mathrm{t}$ voornomd clercschip van de vierboete te bedienen, zonder $\mathrm{t}$ zelve te moghen refuseren, dus hier betaelt over t jaer ... 12 lb. par.". Ib., nr. 37387, rek. 1564-1565, $f^{\circ} 29 \mathrm{r}^{\circ}$.

(157) ,Ander ontfanck van t recht van de vierboete binnen deser stede, ter cause dat elck weerdt over zyne visschers jaerlicx gheeft ende betaelt telcken kersmesse, omme het onderhouden ende bedienen van de zelve vierboete voor huerlieder schepen ter harincteelt, by nachte uut ende in commende, eene groote van elck net, dat ter voornoemde teelt $t$ zeewaerts gaat ... over $t$ saysoen beghinnende september 64 ende hendende daerna ... $98 \mathrm{lb} .7$ s. par.". De lijst somt, per waard, het aantal netten op, waarvoor taks betaald geworden was, namelijk voor de 32 waarden samen 1967 netten. Brussel, ARA, Rekenkamer nr. 37387, rek. 1564-1565, fo $9 \mathrm{v}^{\circ}-10 \mathrm{r}^{\circ}$. - De opbrengst bedroeg in $1565107 \mathrm{lb}$. 2 s. par., betaald door 36 waarden voor 2144 netten; in 1566109 lb. 19 s. par., betaald door 41 waarden voor 2199 netten ; in 1567110 lb. 6 s. par., betaald door 38 waarden voor 2206 netten en in 156896 lb. 6 s., betaald door 36 waarden voor 1926 netten. Ib., nt. $37388, f^{\circ} 9 \mathrm{v}^{\circ}-10 \mathrm{v}^{\circ}$; nr. 37389 , f $80 v^{0}-9 v^{0}$; nr. $37390, f^{\circ} 7 v^{\circ}-8 v^{0}$, en nr. $37391, f^{0} 8 v^{0}-9 v^{0}$, rekeningen over de boekjaren 1565-1569, genoemde rubriek. Zie ook de volgende stadsrekeningen tot en met nr. 37402, boekjaar 1579-1580, waarna de reeks een lacune vertoont tot 1605. Het "officie" van de tresorier als ontvanger van het genoemde vuurboetrecht, duurde telkens van begin september tot einde maart.

(158) ,Adriaen de Clercq, als bediender van de vierboete, danof de stede alsnu d administratie heeft... ter cause van zyn gaigen ende wedden van eenen jare... 36 lb. par.". Ib., nr. 37387 , rek. 1564-1565, f f $^{\circ} 30 \mathrm{r}^{\circ}$. . Zie ook de volgende rekeningen, rubriek ,ander uutgheven van sallarissen, gaigen, wedden ende pencioenen". 
wen en in de rubrieken dicnaangaande opgenomen. Dit was stellig zo voor de aankoop van glui ${ }^{159}$. Wat er ook van zij, over de administratie van de vuurboet door de stadsklerk, evenals over de werking van het baken zelf, vernemen we uit de grenoemde rekeningen niet veel meer dan vroeger. Wel weten we dat het vuur in de ,vierboete" elk jaar slechts van september tot pasen daarna door de "bediender" ervan aangehouden werd ${ }^{160}$. Deze weinige gegevens over de vuurboet te Oostende gaan tot 1580, jaar waarop de laatsie te Brussel bewaarde stadsrekening betrekking heeft.

Oostende werd, zoals de andere Vlaamse steden, in de opstand van de Nederlanden tegen koning Filips II van Spanje betrokken. Aan de kust duurde de strijd tussen de rebellen of Staatsgezinden en de Spanjaarden evenwel langer dan in de rest van Vlaanderen, dat door Alexander Farnese van 1579 tot 1584 grotendeels heroverd werd en aldus opnieuw onder het Spaans gezag was komen te staan. In laatstgenoemd jaar had de bezettingsmacht van de rebellen de duinen ten oosten van de versterkte stad doorgestoken waardoor de onmiddellijke omgeving ervan onder water gezet werd. Door deze overstroming werd tevens een nieuwe havengeul tot stand gebracht, die evenwel eerst later als dusdanig in gebruik zou worden genomen en heden nog steeds bestaat ${ }^{161}$. Of de ,vierboete”, gelegen ten westen van de stad en van de haven dan nog in werking bleef, weten we niet. De plaatselijke zeevisserij en haringvangst was inderdaad in diep verval. Blijkbaar was de vuurboet, die nog steeds overeind stond, nu en dan nog in werking. Althans wordt ze omstreeks 1590 door de Nieuwpoortse auteur Jacob Marchant in diens beschrijving van Vlaanderen, samen met de ,vierboetes" van Blankenberge en Heist, uitdrukkelijk nog steeds vernoemd ${ }^{162}$. We mogen dan ook aanvaarden, dat ze eerst in het

(159) „Betaelt an diverssche persoonen van leveringhe van gleye omme $t$ crammen van den dycken... Welcke leveringhe van gleye bedraghende, midts dat daerinne begrepen es $t$ gley, veroirboort tot de voornomde vierboete, dan of den tresorier met eenen administratie ende last heeft... 593 lb. 16 s. 8 d. par.". Ib., fo $41 \mathrm{r}^{\circ}$. De uitgaven in verband met de aankoop van glui dienden in een ", registre particulier" opgetekend te worden, zodat de tresorier zich om de drie maanden voor de wet op zijin eed kon verantwoorden voor wat aanging „, de menichte van den gleye, als den incoop ende prys van dien, metgaders de persoonen by wien ende up wat daghe $t$ zelve ghelevert" geworden was. - Zie ook de volgende rekeningen, zelfde rubriek.

(160) „Adriaen de Clercq, als bediender van de vierboete deser stede... over zyn gaigen van eenen jaere... dies en compt $t$ bedienen maer inne telckent septembre, als de visschers gaen varen ter haryncteelt ende gheduert tot paesschen daernaer, dat hy boeten moet alle nachtghetyde om de schepen alsdan uut ende invarende, de somme van ende betaelt, 36 lb. par.". Ib., nr. 37397 , rek. 1574-1575, f 33 v $^{\circ}$.

(161) Vlietinck, Het oude Oostende, p. 238 en vlg.

(162) „Pharum ostentat sive turriculam lapideam, ex qua ad regendos navium cursus et praecavenda vada, ignes ex arundine stipulave noctu emicant, quandiu maris fervor allabitur; quales etiam Ostendae, Blancobergae pagoque Heisto conspiciuntur: quae extra oppida sunt et vierboute, ab accensis ex arundine aut stipula flammis, appellantur". J. Marchant, Flandria commentariorum lib. IIII descripta. Uitgave 1596, art. „pharum”. Vertaald luidt deze passage ongeveer als volgt: men bemerkt een "pharus" of stenen torentje, uit hetwelk, om de vaart van de schepen te richten en hen voor de zandbanken te behoeden, 's nachts vuurstralen uit (brandend) riet of stro uitgezonden worden, zolang het opkomend getij van de zee aanblijft : aldus zijn dergelijke (torentjes) te zien te Oostende, Blankenberge en in het dorp Heist, ze 
begin van de driejarige belegering van Oostende, die door aartshertog Albert in 1601 met man en macht ingezet werd, moet verdwenen zijn. $\mathrm{Na}$ de overgave van de volledig verwoeste stad in 1604 kon met de wederopbouw ervan begonnen worden. Van het herstel van de oude haven, gelegen ten westen van de voormalige agglomeratie, en van de vroeger aldaar gelegen vuurboet was evenwel geen kwestic. De ten oosten van de nieuwe stad gelegen geul werd geleidelijk als haven ingericht en in gebruik genomen, zonder dat er onmiddellijk staketsels tot de beschutting van de inkom opgericht werden. Wel werd snel tot de ommuring en bastionering van de nieuwe in vorming zijnde stedelijke agglomeratie overgegaan ${ }^{163}$. Van een eenvoudige nachtelijke verlichting van de haveninkom en geul door twee havenlantaarns blijkt eerst omstreeks 1650 sprake geweest te zijn. Van die tijd af inde de stad van de binnenvarende schepen een loods-, vuur- en kaaigeld ten bedrage van 8 stuivers de last. Strandingen en schipbreuken in de haven leverden evenwel weldra het bewijs dat het signalisatiestelsel er absoluut onvoldoende en dus ondoeltreffend was ${ }^{164}$. Toch moeten we tot 1771 wachten vooraleer dienaangaande een ingrijpen te zien gebeuren. Dat jaar werd inderdaad tot de oprichting van een stenen vuurtoren besloten en tot de uitbreiding van de loodsdienst overgegaan. De vuurtoren, gebouwd op de buitenbastion ten westen van de haveninkom, werd in oktober 1772 in werking gesteld. Aanvankelijk brandde men er steenkolen, maar na enkele jaren diende men op olie en reflectoren over te schakelen. Tenslotte gebruikte men er de lenzen van de Franse natuurkundige Fresnel. Vanaf 1774, toen het loodswezen opnieuw volledig gereglementeerd werd, moesten de Oostendse piloten regelmatig nagaan of het licht van de vuurtoren, evenals dit van de havenlantaars, die vroeger geinstalleerd geworden waren, effectief en doelmatig was. Genoemde vuurtoren, naderhand bijgenaamd ,de Vlaggestok”, wegens de vlag, die er bovenop wapperde, was de eerste in de reeks van vier dergelijke gebouwen, die telkens met steeds modernere apparatuur elkaar tot heden te Oostende zouden opvolgen ${ }^{165}$.

Oostwaarts van Oostende bevond zich in de vijftiende en zestiende eeuw het kleine vuurbaken of ,torrekin" van Wenduine, in 1428 op kosten van

bevinden er zich buiten de agglomeraties en worden er, naar de vlammen ontstoken uit het riet of stro, vierboete genaamd.

(163) Vlietinck, Het Oude Oostende, p. 241 en vlg. - D. Farasyn, Oostende, in Belgische steden in reliëf. Brussel, 1965, p. 139-162, zie p. 22. - R. Baetens, Het uitzicht en de infrastructuur van een kleine Noordzechaven tijdens het ancien regime. Het voorbeeld van Oostende, in Mededelingen, Marine Academie, boek XXIII, jg. 1973-1974-1975. Kapellen 1977, p. 47-62, zie p. 48-49.

(164) Baetens, p. 55 en 60, n. 71. - P. de Zuttere, Les de Vallejo dans les Pays. Bas espagnols et autrichiens, in Intermediaire des Généalogistes, delen 101 en 102, jg. 1962, Extrait, p. 5. Stuk van 12 sept. 1683, ontleding.

(165) J.J. Bowens, Nauwkeurige beschrijving der oude en beroemde zee-stad Oostende. Brugge, 1792, dl. II, p. 145-146. - M. Maes, De vuurtorens van Oostende, in Ostendiana, Oostende, 1972, p. 119-121. - Baetens, p. 55 en 60, n. 73. - Costumen ende usantien der stede ende port van Nieuport, Uitg. P. de Goesin, Gent, 1774, bijlage Costumen ende keuren... van Oostende, p. 105-117, reglement... tot betere directie der lootserie ter haven van Oostende, gedateerd 16 jan. 1773 oude stijl, art. XVIII, betreffende het toezicht op, ,het effect der vieren, soo vanden vier-toren, als van de lanteirens". 
de parochie aldaar opgericht en door het plaatselijk ambacht van de vissers onderhouden, althans - naar het schijnt - voor wat de voorziening van zijn lantaarn aan bruinvisolie betrof. Het gebouw, dat ook als wachthuis voot de vissers diende, stond feitelijk onder het beheer van de proosdij van Sint-Donaas te Brugge, daar Wenduine, als dorp van ", het Proossche" of het gebied, waarvan de proost de heer was, deel uitmaakte en dus van het feodaal bestuur ervan afhing. Het ,,torrekin” blijkt als lichtbaken lang in gebruik te zijn gebleven, vermits in 1538 van herstellingen, die eraan uitgevoerd werden, sprake is. Met het verval van het plaatselijk visserijbedrijf te Wenduine in de loop van de tweede helft van de 16de eeuw, kwam er aan de werking van het vissersambacht en dus blijkbaar ook aan het gebruik van het ,torrekin" als lichtbaken een einde. Overigens verdween dit ambacht als zelfstandige instelling in $1587^{166}$.

Het volgende baken was de, vierboete" van Blankenberge, waarvan de oprichting van omstreeks 1300 moet dagtekenen en de eerste vermelding in een oorkonde van 1337 voorkomt. Daarna wordt ze in 1367 nog vernoemd als deel uitmakend van de keten van de vierboeten, gelegen aan de Vlaamse kust. Ze bevond zich ten oosten van de stedelijke agglomeratie op of achter de aldaar gelegen zeedijk en kaai en ze was lange tijd niet meer dan een houten geraamte ${ }^{167}$. Alhoewel stedelijk, werd ze niet rechtstreeks door de gemeente zelf, maar door een eigen overheid, de „eed”, onder de leiding van een deken en enkele ,,zorgers", bijgestaan door een klerk, bestuurd. De Blankenbergse ,vierboet" was dus een autonome instelling, geschoeid op ambachtelijke of korporatistische leest en zichzelf bedruipend, dank zij de geldelijke bijdragen van haar leden, de plaatselijke vissers. Deze financiering gebeurde door middel van een jaarlijkse "ommestellinghe" of omslag waardoor de gezamenlijke lasten onder de leden of vissers gelijkelijk verdeeld werden. Ze diende om de kosten van onderhoud en werking van de ,vierboete”, de aankoop van brandstof, namelijk glui en stro, en de wedde van de ,vierboeter" of stoker te dekken. Hoeveel de jaarwedde van deze laatste bedroeg, weten we niet. Wel kwam de stad Blankenberge op de duur meer en meer de vuurboetinstelling te hulp, als die bepaalde financiële verplichtingen niet of niet volledig kon naleven ${ }^{168}$. Dat de Blankenbergse ,vierboete" lange tijd niet meer dan een houten stellage of steiger was, blijkt uit de vernieuwing van haar houtwerk door een timmerman tijdens het dienstjaar 1421-1422, wat door de stad be-

(166) P. Verduyn, Gescbiedenis von Wenduine. Wenduine, 2e herwerkte druk, 1960 , p. 98, 130 en 141-144 passim. - Van het ,torrekin" is et nog in 1572 sprake. Zie ibidem p. 145, kaartje met lokalisatie van het "torrekin".

(167) ,dat men den zee dyc te Blankenberghe in die oost port betren soude, daer $s$ nood ware, ende dat men den dyc hoghen soude viere voeten met aerden van der vierboete oostwaerd toten polrekine boosten baelgen". C. Carton, Notice sur Blankenberge, 1841, p. 76-82, tekst van een oorkonde van 1337 betreffende de plaatselijke wateringen. Zie p. 79. - M. Coornaert, De zeewering van de Oudemaarspolder, in Rond de Poldertorens, 8ste jaar, nr. 2, 1966, p. 61. - Zie nr. 10.

(168) Van een persoon, genaamd Michiel de Vierboeter, die in een ,zettinghe" een "firling" te betalen had, wordt in de stadsrekening van Blankenberge over het boekjaar 1419-1420 melding gemaakt. Brussel, ARA, Rekenkamer nr. 32158, f $2 \mathrm{v}^{\circ}$. Zie voor de "vierboete" zelf, ibidem, fo $6 \mathrm{r}^{\circ}$. 
kostigd werd ${ }^{169}$. Als gebinteconstructie in hout moet ze veel gelijkenis vertoond hebben met de toenmalige Oostendse vuurboet, die eveneens in hout was.

In de loop van 1442 werd de Blankenbergse, vierboete" zo zwaar door brand getroffen dat ze volledig wederopgebouwd diende te worden. Daartoe riepen de schepenen de vrijwillige financiële steun van de kooplui en schippers te Sluis in. Het nieuwe baken dat na een jaar tot stand kwam, was blijkbaar een toren in steen en hout, maar bijzonderheden daarover vernemen we niet. Wel weten we dat de ,zorgers", om de eerste werken te kunnen laten uitvoeren, zich verplicht gezien hadden van een onder voogdij staande wees geld te lenen en dit naderhand niet volledig konden terugbetalen, zodat de gemeente het tekort diende te vereffenen ${ }^{170}$. Dat de Blankenbergse ,vierboete", althans van een zeker ogenblik af, in steen was, staat vast. In 1484 inderdaad bekostigde de stad de verbouwing in steen van de kap van dit gebouw. De uitgaven voor de aankoop en het vervoer van bakstenen, balken en kalk, alsmede voor de lonen van de metselaars en andere werklieden, die het werk uitvoerden, vinden we in de Blankenbergse stadsrekening lopend over het ambtsjaar 1484-1485 genoteerd. Daardoor vernemen we tevens, dat op de makelaar of rechtopstaande stijl, zich bevindend op de nok aan de spits, een nieuwe weerhaan geplaatst werd ${ }^{171}$. Naderhand bleven de Blankenbergse schepenen

(169) ,Item, betaelt Jan de Juede, de temmerman, van den houtwerke van der vierboete te makene, besteit bi der wet ende dit in minderinghe, $2 \mathrm{lb}$. $16 \mathrm{~s} . g \mathrm{r}$. Item, betaelt van naghelen, van ankeren ende ghehanghen, $34 \mathrm{gr}$. Item, betaelt van lyfcope, als Jan de Juede de vierboete nam te makene, 5 s.gr.". Ib., nr. 32160, rek. 1421$1422, \mathrm{f}^{\circ} 3 \mathrm{r}^{\circ}$.

(170) „Item, betaelt Cornelis fs Godevaerts van der vierboete scone te makene van den asschen ende brand hute te doene, 10 gr." - „Item, ghezent ter Sluus an de cooplieden ende scipmannen, te wetene wat ze precenteeren wilden ten costen van der vierboeten, waert up dat men se weder maken mochte, omme daer in te vierne, also men oyt geploghen heift, hier omme uut zijnde Joriis But ende Jacob Pascharis elc 1 dach...". Ib., nr. 32175, rek. 1442-1443, fo $3 r^{\circ}$ en $6 v^{\circ}$. - Item, ghegheven ten costen vaert van der vierboete van Blankenberghe omme Christiaen van der Sleke ende Jacob Stier mede te betaelne, dat zij an de voorseide vierboete ghewrocht hadden, 9 s.gr.". Nr. 32176, rek. 1443-1444, fo $4 \mathrm{v}^{\circ}$. - „Item, betaelt J. fs Clais Buekels van dat zijne voochden in $t$ jaer $(14) 43$, als doe de vierboete van der stede verberent zijnde, leende(n) den ontfangher ende zorghers van der voorseide vierboete, daer mede betaelt Christiaen van der Sleke, ende dat over t laetste paeyment van zijnen voorseide taswerke, 3 lb. gr.". Nr. 32178, rek. 1444-1445, fo 5 v $^{0}$. Chr. van der Sleke was waarschijnlijk een metselaar. Zie n. 171. - In de periode 1467-1484 is er meermaals sprake van werken tot onderhoud van de houten ,kaye van der vierboete”. Deze „kaeye, staende in den dunen voor de vierboete”, diende "jeghen $t$ vloeden van der zee" door middel van zand en aarde en ook planken versterkt te worden. Ib. nrs. 32200-32216, rekeningen 1467-1484, rubriek „diverssche costen".

(171) Voor dit werk waren aangekocht geworden 1 last 2000 bakstenen, 62 ,, hoet calcx", 5 "Vlaemsche houten, daer de cruushouten of ghemaect" waren, 6 nieuwe ankers en een "ysserin spille, staende boven up de makelare, daer de wederhane up staet". Ook deze windwijzer was nieuw. Na aankoop had men hem bovendien geschilderd en verguld, vooraleer hem op zijn spil te plaatsen. Een viertal metselaars en werklieden blijken, afwisselend, gedurende een drietal maanden aan de nieuwe vuurboet "ghemaetst" en ,ghewrocht" te hebben. Een van hen was "Christaen van der Sleke, maetsenaere". Ib., nr. 32217, rek. 1484-1485, fo $6 \mathrm{v}^{\circ}-7 \mathrm{r}^{\circ}$, , rubriek „, costen 
financieel bijspringen, telkens als de vuurboetinstelling voor het onderhoud van haar gebouw zekere uitgaven niet kon opbrengen. Alhoewel de stadsrekeningen uit de periode 1485-1499 ontbreken, weten we dat de gemeente in 1493 geldelijk deze instelling gesteund had, klaarblijkelijk door in haar plaats zekere herstellingswerken aan het houtwerk van de „vierboete" of de aankoop van het daartoe benodigde hout te bekostigen. Om dit te doen had ze zich zelfs tegenover een timmerman of houthandelaar door kontrakt verbonden tot afbetaling van haar schuld op een bepaald termijn, maar schoot daarbij te kort en kon eerst in 1503 voldoen ${ }^{172}$. In $1511,1512,1516$ en 1520 nam ze het nogmaals op zich telkens een kleine uitgave voor herstellingen aan de vuurboet te bekostigen ${ }^{173}$. In 1524 werd de kap van dit gebouw op haar kosten hersteld en "verschoond", wat de aankoop van een groot aantal dektegels en andere gebakken stenen, alsmede kalk en teer meebracht en na de voltooiing van het werk met het plaatsen van een nieuwe weerhaan op de top gepaard gegaan was. Datzelfde jaar, tijdens de oorlog tussen keizer Karel $V$ en de koning van Frankrijk, toen Franse oorlogsschepen met vijandelijke bedoelingen vóór de kust verschenen, zorgden de schepenen er telkens voor dat de vuren in de duinen en op de vuurboet ontstoken werden, ten einde de vijand diets te maken dat men wakkzaam en klaar voor de verdediging was. Voor het eerst vernemen we uit de desbetreffende rekening dat de daarvoor gebruikte brandstof uit glui en stro bestond ${ }^{174}$. Overigens kon de vuur-

ghedaen an de vierboete van Blanckenberghe, de cappe boven te verlegghene ende nieu te makene..."

(172) „Item, den aeldinghers van wylen Adriaen Stier in de somme van elleven ponde zestien schellinghen groten, als reste van meerder somme, ter cause van der vierboete van deser stede, als blyct by eene lettre van verbande onder den zeghele van der stede, danof breeder ghewaghende, in daten van den 6 den daghe van maerte anno $1493 \ldots .$. . Ib., nr. 32220, rek. 1502-1503, f $29 \mathrm{v}^{\circ}$. - A. Stier had in 1484, bij het vernieuwen van de "kappe", 5 "Vlaemsche houten" voor het maken van de „cruushouten” geleverd. Zie n. 171. Ongetwijfeld was hij een timmerman.

(173) De stad bekostigde in 1511 de aankoop van ,24 stylen, elc 14 voeten lanc", dienende voor 't maken van eender nieuwer caeye ter preservacie ende beschermenesse van der vierboete deser stede jeghen de stormen ende hooghe vloeden van der zee". Ib., nr. 32229, rek. 1511-1512, f $12 \mathrm{r}^{\circ}$. - Het volgende jaar dekte ze de uitgave voor de aankoop van 600 ,, naghels an de calzie van der vierboeten verbesicht". Nr. 32230 , rek. $1512-1513, f^{\circ} 11 \mathrm{r}^{\circ}$. - In 1516 bekostigde ze het vervoer van kalk "omme t repereren van der vierboete" en ook de reparatie zelf. Nr. 32234, rek. "1516-1517, fo $6 \mathrm{r}^{\circ}$. - In 1520 betaalde ze de uitgave voor de aankoop van, ,acht hanckers an de vierboete... verwrocht ende gheorboort, weghende hondert ende vichtich ponden ysers...". Nr. 32238, rek. 1520-1521, fo $5 \mathrm{r}^{\circ}$.

(174) „Item, betaelt Michiel van Langhemaerc, metsenare, van de cappe van den vierboete... te verscoenene, die te terrasene, te bezettene ende andre reparacie by hem daeran ghedaen, hem in taswercke besteedt... Item, betaelt van 19 hoet Brabants calc ende twintich tonnen terras, van dectichelen ende careelsteenen an de zelve vierboete gheorboort metten eenen weerhane”. - „Item, betaelt diversche personen van te vierne up de vierboete ende vieren te makene by nachte up de dunen deser stede jeghens de scepen van orloghen Fransoeisen, wesende hier voor lant, ten fine, dat zy te bet hemlieden verdraghen zouden an lant te slane, midts dat men by den zelven vieren hemlieden tooghde, dat men in waeke ende roere was. Item, betaelt van gleye ende stroe omme $t$ maken van den zelve vieren ende daer verbrandt...". Ib., nr. 32242, rek. 1524-1525, fo $6 \mathrm{v}^{\circ}$ en $15 \mathrm{r}^{\circ}$. - Ook werden op de duinen nog twee masten opgesteld, voorzien van twee „fockezeilen", steeds „omme 
boetkorporatie het volgend jaar wegens de oorlogstoestand, die de normale uitoefening van de zeevisserij belemmerde, de lopende uitgaven in verband met de aanschaffing van stro niet volledig vereffenen, daar de gebruikelijke "ommestellinghe" onvoldoende opgebracht had. De gewone jaarlijkse opbrengst van deze heffing bedroeg inderdaad 16 tot 18 pond groten, althans in die tijd, en dit werd niet bereikt. De gemeente Blankenberge evenwel droeg het hare tot de vereffening bij door een som van 4 pond groten toe te leggen ${ }^{1 i 5}$.

In de tweede helft van 1526 of het begin van 1527 werd de Blankenbergse ,vierboete" door brand van haar houten binnenwerk, waaronder de zolderingen, zwaar getroffen. Van het herstel van gebouw maakte men echter gebruik om in de stenen muren naar het voorbeeld van wat reeds in de "vierboetes" van Nieuwpoort en Oostende bestond drie vensters aan te brengen. Met het oog daarop hadden de Blankenbergse wethouders zelf voorafgaandelijk drie metselaars naar deze stenen vuurbakens gestuurd om er de vensterapparatuur te gaan bezichtigen. Het was nogmaals de stad Blankenberge die de uitgevoerde werken en andere lasten bekostigde. Ten behoeve van de ,vierboeter" was in het gebouw ook een ladder en, voor het naar boven hijsen van de bussels stro, een hijsblok voorzien van een reep aangebracht geworden. Dit alles ging gepaard met de vernieuwing van heel wat ijzerwerk ${ }^{176}$. Gedurende het ambtsjaar 1527-1528 bekostigden de schepenen opnieuw zekere reparaties aan de zolderingen en vensters van de "vierboete". In de loop van 1528 diende men, gezien de vijandelijkheden op zee, enkele keren in de duinen en op de vuur-

de visschers... wezende ter zee baken ende teeken te ghevene jeghens de Fransoeisen". Ib., $f^{\circ} 5 r^{\circ}$.

(175) „Item, uute dien dat men alle nachte up den torre van deser stede, staende up den dunen ende den ouver van der zee, ghenaemt de vierboete, vier maken moet met stroe omme den visschers teecken te ghevene, ten fine dat zy weten moghen waerontrent zy zyn ende ariveeren moeten, $t$ welke vierboeten jaerlycx by ommestellinghe ten laste van den zelven visschers wel bedraeght ter somme van 16 of $18 \mathrm{lb}$. gr. Nemaer, midts den orloghe ende datter diversche van hemlieden van den Fransoeisen ghevanghen gheweest hebben ende groot renchoen moeten betalen, zo en es hemlieden dit jaer niet moghelic gheweest ten voorseide lasten gheheel te furnierne, als waerby hemlieden by die van der wet, $\mathrm{t}$ hulpen den lasten voorscreven, toegheleit es de somme van $4 \mathrm{lb}$. gr.". Ib., nr. 32243, rek. 1525-1526, fo $10 \mathrm{v}^{\circ}$. - Uittreksels uit de Blankenbergse stadstekeningen vanaf dat boekjaar in: E. Van den Bussche, Blankenberghe et son passé historique. La Flandre, dl. VII, 1875, p. 248 en vlg.

(176) ,Item, betaelt Heindric Kint, temmerman, van $t$ maken van der vierboete deser stede, die binnen al verberrent was, metgaders de balken, zolders ende ander hautewerc by hem daertoe ghelevert ... Item, betaelt den zelven Heindric van $t$ maken van drie veinsters an de zelve vierboete, metgaders $t$ hout ende berden by hem dertoe ghelevert ... Item, betaelt van vier hout Brabants calcx an de zelve vierboete verme $(t)$ st ende verbesicht ... Item, betaelt Sebastiaen Paes van eender leere ende eenen reep omme stroe daermede in de zelve vierboete up te haelne, metgaders eenen bloc daertoe dienende... Item, betaelt Jacop Kint van diverssche yserwerc...". „Item, ghereist (door drie man, waaronder een metselaar) t Oesthende ende van danen ter Nieupoort omme te bescauwene ende concept te nemen van den fatsoene van den veinsters van der vierboete van den voornomden steden, omme de veinsters van der vierboete deser stede daer naer te makene". Brussel, ARA, Rekenkamer, nr. 32244 , rek. mei 1526 - april $1527, f^{\circ} 4 \mathrm{v}^{\circ}$ en $8 \mathrm{v}^{\circ}$. De brand was door zowat tien man bestreden geworden. - R. Boterberge, Over de vuurtorens van Blankenberge, in Biekorf, dl. 81 , jg. 1981, p. 260-268. Zie p. 260-261. 
boet vuren te ontsteken ten einde de vissers sein en teken te geven en de Franse oorlogsschepen vóór de kust af te schrikken ${ }^{177}$. De samenwerking tussen de vuurboetkorporatie en de gemeente Blankenberge blijkt in het vervolg nog nooit zo goed geweest te zijn. Van 1539 af inderdaad schonk de Blankenbergse magistraat elk jaar de deken, de „zorgers" en de eed van de vuurboet, als present, acht kannen wijn ${ }^{178}$. De gemeente droeg ook verder de kosten van de herstellingen aan het metselwerk van dit gebouw, telkens als dit nodig was, onder meer tijdens de dienstjaren 1539$1540,1548-1549,1550-1551,1551-1552$ en 1553-1554. Ook voor het aanbrengen van glas in de vensters werd gezorgd ${ }^{179}$. Het moet wel zijn, dat de muren van de Blankenbergse ,vierboete", als zijnde voortdurend aan weer en wind blootgesteld, telkens na enige tijd uitgevreten geraakten of barsten vertoonden, zodat ze dan steeds opnieuw ,,vermetst" dienden te worden. Zulk een metselwerk greep gedurende het ambtsjaar 1555 1556 plaats. Daarbij bekostigde de stad de aankoop en verwerking van grote hoeveelheden steen, kalk en teer ${ }^{180}$. In de loop van het volgend dienstjaar lieten de Blankenbergse schepenen door een bevoegd ambachtsman overgaan tot het maken en opstellen van een "patroon" van de werken nodig voor het behoeden van de agglomeratie, de kaai en de vuurboet tegen de ontzanding en de zeeirruptie ${ }^{181}$. Blijkbaar kwam het niet tot de uitvoering van zulk een algemeen plan, vermits we de volgende jaren de stad verder zien gaan met de bekostiging van de herstellingen aan

(177) „Item, betaelt Heindric Kint van diversche reparacie by hem ghedaen an... de veynsters ende zolders van der vierboete... mitgaders $t$ hout by hem daertoe ghelevert...”. - „Item, betaelt van stroe, verberrent up de vierboete ende up den dunen, omme vier te makene jeghens den Fransoeysen ende omme teecken den visschers deser stede te ghevene...". Ib., nr. 32245, rek. 1527-1528, fo $6 \mathrm{r}^{\circ}$ en $13 \mathrm{r}^{\circ}$. Om de vissers op zee te waarschuwen waren in de duinen ook twee masten, voorzien van touwen, zeilen, blokken en "stylen”, opgesteld geworden. Ib., fo $6 \mathrm{r}^{\circ}$.

(178) „Item, ghepresenteert de zorghers ende deken van der vierboete deser stede vier cannen wyns...". Ib., nr. 32251, rek. 1533-1534, fo $10 \mathrm{r}^{\circ}$. - "Ghepresenteirt den deken, zorghers ende eedt van der vierboete 8 kannen wyns...". Nr. 32265, rek. 1547-1548, fo $9 \mathrm{r}^{\circ}$. Acht kannen vanaf nr. 32257, rek. 1539-1540, fo $11 \mathrm{r}^{\circ}$. - Voor de eed van het vissersambacht zelf, zie E. Van den Bussche, La pêche et les pêcheurs de Blankenberghe. Mœurs et coutumes, in La Flandre, dl. VIII, 1876, p. 347-464, zie p. 349 en vlg., hoofdstuk: La corporation des pêcheurs depuis le moyen âge. De vuurboetinstelling had dus een soortgelijke organisatie als het vissersambacht, waarvan de leden haar kas spijsden.

(179) „Betaelt Gillis Bultynck, glaesmaker in Brugghe, over de reparatie ... van der lanteirne in de vierboete". Brussel, ARA, Rekenkamer nr. 32262, rek. 1544-1545, $\mathrm{f}^{\circ} 4 \mathrm{r}^{\circ}$. - „Betaelt Gillis Bultynck, glaesmaeker in Brugge, ter causen van drie nieuwe glaese veynsteren by hem ghelevert an de vierboete... Betaelt Jan Lammin, maetsenaere deser stede, voor dat hy de vierboete... vermaect heeft binden jare...". Nr. 32268, rek. 1550-1551, fo $5 \mathrm{r}^{\circ}$. - Voor de reparaties aan het metselwerk zie ook nr. 32257 , rek. 1539-1540, fo $3 \mathrm{v}^{\circ}$; nr. 32266, rek. 1548-1549, fo $5 \mathrm{r}^{\circ}$; nr. 32269, rek. $1551-1552, f^{\circ} 5 \mathrm{v}^{\circ}$, en nr. 32271 , rek. $1553-1554, f^{\circ} 5 \mathrm{v}^{\circ}$.

(180) Een metselaar werkte gedurende 25 dagen aan de herstellingen en gebruikte daarbij zowel oude, door hem gehouwen stenen, als nieuwe bakstenen. Ib., nr. 32273, rek. 1555-1556, fo $5 \mathrm{v}^{\circ}-6 \mathrm{r}^{\circ}$.

(181) „Betaelt meester Anthonis Heyndricx, werckman up t ambacht, van by hem ghevaciert $t$ hebbene diversche daghen in $t$ steken ende maken van de patronen van de wercken, noodzakelyk wesende ter preservacie van der stede, kaye ende vierboete...". Ib., nt. 32274, rek. 1556-1557, f $5 \mathrm{v}^{\circ}$. 
de muren van de ,vierboete", waaronder ook het aanbrengen van drie houten vensters. Voor het overige trof ze de gebruikelijke maatregelen tot vrijwaring van de "clytdyck" nabij de vuurboet en van de onmiddellijke omgeving van dit gebouw, waar de ontzanding door zandverstuiving gevaarlijk toegenomen was ${ }^{18: 2}$.

Een nieuwe brand teisterde de Blankenbergse "vierboete" in de tweede helft van 1566 of het begin van 1567. De gemeente bekostigde de aankoop van heel wat hout, kalk, stenen en ijzer, alsmede de betaling van de lonen aan de timmerman, de metselaar en de smid, die de nodige herstellingen uitgevoerd hadden. Nieuw was zeker wel het aanbrengen in of onder het gebouw van een stenen vloer, evenals een uitrusting met ijzeren deuren ${ }^{183}$. In 1568 diende men niet alleen de ,clytdyck”, maar ook de bodem, waarop de vuurboet stond, met kramwerk of matten, verder te versterken. Daarvoor werd door de stad een grote hoeveelheid glui aangekocht ${ }^{184}$. Deze werken tot vrijwaring van de Blankenbergse „vierboete” en naderhand ook de volgende hadden alvast de verdienste het bestaan van dit gebouw te rekken tot op het ogenblik, dat het, op het einde van de 16de eeuw, onder invloed van de politieke en militaire gebeurtenissen aan zijn lot overgelaten werd en verdween. De strijd aan de kust tussen Staats-

(182) „Betaelt Michiel Ardebolle van drie houten veynsteren an de vierboete...”. Ib., nr. 32280 , rek. $1562-1563$, fo $4 \mathrm{v}^{\circ}-5 \mathrm{r}^{\circ}$, waar ook andere uitgaven voor herstellingen aan de vuurboet genoteerd staan. - Op 12 oktober 1560 trok de Blankenbergse stadspensionaris naar Brugge om er bij het bestuur van het Brugse Vrije ,te vertoghene den noodtzakelicke toezich(t) jeghens den vloghe van de zande ontrent de vierboete deser stede, ten fyne derinne voorzien zoude worden ten minste coste deser stede...". Nr. 32278, rek. 1560-1561, fo $6 \mathrm{r}^{\circ}$. Zie aldaar ook fo $4 \mathrm{r}^{\circ}$ voor reparaties aan de vuurboet. - Betreffende de uitgaven voor het "crammen" of versterken met matten in stro van de ,clytdyck van de vierboete", "zie nr. 32279, rek. 1561-1562, fo $4 \mathrm{v}^{\circ}$, en volgende rekeningen, rubriek, ,van reparatien ende refectien". Soms gebruikte men ook ter versteviging van de basis van de "vierboete", zoals vroeger al gebeurd was , in den grooten vloet", grote hoeveelheden "pemen" of wortels. Ib., nr. 32269, rek. 1551-1552, fo $6 \mathrm{r}^{\circ}$ : eerst 75 , voeren pemen", daarna 49 voeren. - Zie voor het overige nr. 32281 , rek. $1563-1564$, fo $4 \mathrm{v}^{\circ}$ en $10 \mathrm{v}^{\circ}$, nr. 32282 , rek. 1564-1565, fo $5 \mathrm{r}^{\circ}$ en $\mathrm{v}^{\circ}$, en nr. 32283, rek. 1565-1566, fo $4 \mathrm{v}^{\circ}$.

(183) ,Betaelt Pauwels van de Berghe, temmerman binnen Brugghe, voor zyn handtghedaen ghedaen (sic) an de vierboete deser stede by brande bedorfven... Betaelt Jooris de Pape, den smet tot Brugghe, voor diversche ankeren ende yseren duerkins an de zelve vierboete gheorboort... Betaelt Maerten Rombouts voor de zelve vierboete in zyn metsement te heelene ende van den vloer te legghene, volghende zeker bestedinghe met hem ghemaect". Ib., nr. 32284, rek. 1566-1567, fo $4 \mathrm{r}^{\circ}-5 \mathrm{v}^{0}$. Tegelijk diende de "clytdyck" "ghestopt" te worden, wat tweemaal gebeurde. Ib., $f^{\circ} 5 \mathrm{v}^{0}$.

(184) „Betaelt Joos van Loo van de clytdyck an de vierboete te crammene... Betaelt der weduwe Zacharias Pierins voor twee hondert vyftich gheley omme de vierboete te crammene... Betaelt Gheraert d Hondt voor 358 bonden gheley omme de vierboete te crammene... Betaelt Hector Batens ende Fransoys Mahieu van gheleye... Betaelt den voornoemde Gheraert d Hondt van de clytdyck anne de vierboete le legghene..." enz. Ib., nr. 32286, rek. 1568-1569, f ${ }^{\circ} 5^{\circ}$ en $6 \mathrm{r}^{\circ}$. - Reeds het jaar voordien waren 450 ,gheley" voor het krammen van de "clytdyck van de vierboete" gebezigd geworden. Nr. 32285, rek. 1567-1568, fo $5 \mathrm{r}^{\circ}$ en $\mathrm{v}^{\circ}$. - Zie ook nr. 32287, rek. 1569-1570, fo $6 \mathrm{r}^{\circ}$ : uitgave om, ,den clytdyck anne de vierboete te stoppene ende (voor) eenen nieuwen matte". 
gezinden en de Spanjaarden was inderdaad voor Blankenberge noodlottig, vooral vanaf 1576 . In een zeeboek uit die tijd staat de zich aldaar bevindende ,vierboed" nog aangeduid. Omstreeks 1590 wordt ze ook nog door Marchantius vermeld, maar of ze toen nog werkelijk overeind stond en functioneerde, valt te betwijfelen. De Blankenbergse stadsrekeningen uit de periode gaande van 1577 tot 1607 ontbreken immers, zodat we niet kunnen nagaan wat er van haar geworden is. Wat er ook van zij, naderhand is er te Blankenberge alleen nog van een vuurbaken onder de vorm van een met een lamp voorziene mast sprake ${ }^{185}$.

Het dichtst bij de inkom van het Zwin stond de „vierbote” van Heist, reeds vermeld in een rekening over het boekjaar 1363-1364 en dus waarschijnlijk toen reeds enkele tijd bestaand. Nadien wordt ze in het vijftiendeeuws Vlaamse zeeboek vernoemd. Samen met de vuurboet van Blankenberge vinden we ze nog aangeduid in het ander besproken zeeboek, dagtekenend van omstreeks 1576. Zoals deze toren, wordt ze ten slotte ook door Marchantius rond 1590 voor het laatst beschreven ${ }^{186}$. Volgens een gegeven uit het jaar 1642, voorkomend in een leenboek van de burg van Brugge, was de Heistse ,vierboete" een achterleen, afhangend van het Hof van Dudzele of de heerlijkheid van die naam. De heer of de rechthebbende van dit feodaal goed verpachtte het baken aan de vissersgilde Onze Lieve Vrouw van Heist tegen een vaste jaarlijkse pachtsom, ten bedrage van 12 pond groten en 3 stuivers, en de verplichting het gebouw, dat in steen was en in de duinen stond, in goede staat te houden. Wegens de oorlogstoestand en het verval van de Heistse zeevisserij kon de gilde evenwel toen haar verbintenissen niet meer nakomen, zodat het vuurbaken de heer van Dudzele geen opbrengst meer opleverde ${ }^{187}$. Enkele jaren later ging de parochiale kerk van Heist, die de plaats van de gilde ingenomen had, tot de afbraak van de bouwvallige „vierboete" en de verkoop

(185) Zie n. 24 en 162. - E. Vanden Bussche, in La Flandre, Revue, dl. VIII, p. 27-40, 157-178 en 239-280. Zie p. 155-156 over de ,viermast" en een proces daarover tussen de vissers van Blankenberge en die van Wenduine vóór de proosdij van Sint-Donaas in 1467, datum, die blijkbaar op een drukfout berust (1767?), en p. 241-244 over de invallen van de geuzen. - Zeker is, dat in de 18 de eeuw de nering of het ambacht van de Blankenbergse ,vrije visscherij" voor het onderhoud van de ,vierbake" of "viermast" instond en dat haar leden daarvoor een ,viergheld" verschuldigd waren. Dat blijkt uit haar rekeningen uit die tijd, die in de kerkfabriek van Sint-Antonius te Blankenberge bewaard bleven.

(186) "te Heys bewesten der vierboten". Rek. van de watering Eiesluis van 1363-1364, M. Coornaert, Heist en de Eiesluis (Reeks Coornaert, II), Tielt, 1976, p. 457, alf. reg., nr. 374, verbo, ,vierbote". - Zie n. 24 en 162.

(187) „Item, zoo competeert de voornoemde mevrauwe (Mher Vrauwe Magdeleene Eegmont, douagiere van den hooghen ende moghenden prince Alexander de Croy), ter causen van der heerlichede van Dudzeele, de vierboete van der duynen van der zee, de welcke den heere voormaels verpacht heeft an de gilde broeders van de gilde van onse Vrauwe tot Heyst, ten pryse van twaelf ponden grooten ende drye stuvers $t$ siaers suver gelt, boven de reparatie ende onderhoudynghe van der voornoemde vierboete, die de voornoemde ghilebroeders waeren schuldich te doene, onvermindert heurlieder pacht, ende alsoo tot Heyst omme de oorloghe gheen visschers meer uut en vaeren, soo en proffyteert den heere danof niet voor alsnoch". Brugge, Rijksarch., fonds Leenhof van de Burg van Brugge, nr. 5, dl. i, fo $189 \mathrm{r}^{\circ}$, anno 1642. - Coornaert II, p. $146,375-376$ en 457, alf. reg., nr. 374. 
van de daardoor gerecupereerde stenen over ${ }^{188}$. Met de verdwijning van dit vuurbaken bleef er van de ,vierboetes", die aan de kust ten oosten van de IJzermonding stonden, geen enkele meer over. Niets illustreert dan ook meer het diep verval van de vissersnering in genoemde streek rond 1600 dan dit schijnbaar weinig belangrijk feit.

\section{De vuurboeten van de Hollands-Zeeuwse kust van Brielle tot Westkapelle}

Een belangrijke vuurbaken tevens landmerk op de hanzeroute naar het westen was ongetwijfeld het dubbele teken te Brielle, aan de monding van de Maas, op het eiland Oost-Voorne, tussen Zeeland en Holland. Door een oorkonde van 8 december 1280 had Aelbrecht, heer van Voorne en burggraaf van Zeeland, aan de parochiale kerk en de tafel van de Heilige Geest of armendis de toelating verleend tot de oprichting en uitbating van twee ,viereberghen", die zowel 's nachts als over dag als bakens dienden te fungeren. De renten of inkomsten, door deze uitbating opgebracht, waren door hetzelfde privilegie aan beide genoemde parochiale instellingen toegekend geworden ${ }^{189}$. Ongetwijfeld zijn daarna de twee vuurbakens onder de vorm van een op een natuurlijke of kunstmatige hoogte aangelegde haard tot stand gekomen en inden de parochiale instanties van Brielle van de voorbijvarende of aankomende schepen een vrijwillige of vaste bijdrage tot onderhoud van de bakens en de nachtelijke vuren. Wat er ook van zij, toen de heer van Voorne, blijkbaar Gherard, in 1320 of kort ervoor, overging tot de invoering van een nieuwe regeling betreffende de heffing van deze bijdrage, lokte dit verzet uit vanwege de graaf van Zeeland en Holland, die, in naam van de kooplui en de zeelui, aan wie hij geleide doorheen zijn vorstendommen te verschaffen had, ingreep. Door een grafelijke verordening, uitgevaardigd op 15 augustus 1320, werd inderdaad het ,debitum nocturni signi maris", als ongeoorloofd afgewezen en de heer van Voorne aangemaand zich aan dit bevel te houden, wat tevens inhield dat hij geen soortgelijke regeling meer mocht treffen, noch vaartuigen of kooplui, wegens ontstentenis van betaling van de geëiste bijdrage, arresteren ${ }^{190}$. Dit grafelijk verbod was evenwel niets

(188) Coornaert II, p. 155-156, naar de kerkrekening 1641-1643 en volgende rekeningen. Nog in 1647, nadat een storm de resten van de grondvesten bloot gelegd had, konden aldus stenen gerecupeerd en verkocht worden.

(189) „Dat ik (Aelbrecht) hebben ghegheven der kerken ende den Heiligen Geeste ten Briele orlof te makene twee viereberghen ten ouden Brielen ende die viereberghen te achterwaernen, als er toe horet, omme oerbare der goeder lieden, die die zee zoeken, beyde by nachte ende by daghe, ende omme dat si diet doen sullen getrouwelike, so gheve ic der voreghescreven kerken ende den voirghescreven Heiliggen Geest al die rente, die daer of comen sal, ewelicke te hebbene ende te besittene, also langhe alse si die viereberghen moghen houden van der zee...". K. van Alkemade en P. van der Schelling, Beschryving van de stad Briele en den Lande van Voorne. Rotterdam, 1729, dl. II, Privilegiën, p. 9-10, nr. XVII, tekst van de oorkonde uit het gemeentearchief te Brielle.

(190) „Cum nuper intelleximus, quod dominus de Voirne, noster consanguineus, quedam nova statuta super mercatores, ante villam de Briel in nostro conductu transire volentes, emanare fecerit, videlicet, ut ad dictam villam de Briel arivarent et ibidem terram ascenderent, propter debitum nocturni signi maris persolvandum, 
meer dan een poging tot intimidatie en haalde dan ook niets uit. De heer van Voorne was immers een feodale machthebber, die zich tegenover de graaf van Zeeland en Holland als onafhankelijk gedroeg en de monding van de Maas als zijn souverein gebied beschouwde ${ }^{191}$. Dat hij op de grafelijke intimidatie niet inging, blijkt uit zijn verder gedrag. Inderdaad reeds op 10 november 1321 regelde de heer van Voorne, Gherard, door een besluit, de voorwaarden, waarin de kooplui en zeelui van Kampen die de haven van Brielle aandeden, er mochten aanleggen en er aan de „,viirboetmeysters" het „viirboetghelt" te betalen hadden. Uit dat stuk blijkt dat het beheer van de Brielse vuurbakens - waarvan de nieuwe naam, vuurboeten, aan een verbouwing doet denken - nog steeds parochiaal was, aangezien het zich in de handen van vuurboetmeesters bevond, die vuurboetgeld mochten heffen. Tevens vernemen we wat de lieden van Kampen als dusdanig ,ghelt" voor het aandoen van de Brielse haven verschuldigd waren, namelijk acht groten voor elke kogge en vier voor elke ever, telkens slechts één maal per jaar te betalen ${ }^{192}$. Krachtens een beslissing van dezelfde Gherard, heer van Voorne, van 1 juni 1333, mochten de Brielse vuurboetmeesters de voet van het vuurboetgeld voortaan zelf vaststellen en dit in overeenstemming met de onkosten door hen gemaakt voor het onderhoud van de vuren. Tevens werden sankties voorzien ten overstaan van de stuurlui-vissers, die, na de beëindiging van de haringteelt, na zouden gelaten hebben de door hen verschuldigde vuurbakenrechten te vereffenen en wel door middel van beslaglegging op hun goederen, want of schip ${ }^{193}$. Belangrijk was ook het initiatief genomen door

nos vero... adhoc remedium preposuimus adhibere, signantes omnibus mercatoribus... quod dominus de Voirne predictus de talibus statutis, arrestationibus, seu occupationibus magnis abstinebit et quod omnes et singulos veros mercatores ipsorum rebus et mercandisiis a dicta arrestatione seu molestia de cetero defendemus...". F. van Mieris, Groot cbarterboek der graven van Holland, Zeeland en beeren van Vriesland. Leiden, 1753-1756, dl. II, p. 238. Op te merken is dat het mandement gericht is tot de „universis et singulis mercatoribus terras Hollandie vel Zelandie transire volentibus vel ibidem cum ipsorum magnis navibus, aut aliis cum quibusque mercaturis arivantibus". Met „magnis navibus" kunnen koggen bedoeld geweest zijn.

(191) S.P. Haak, Brielle als vrije en bloeiende handelsstad in de 15de eeuw, in Bijdr. voor vaderlandse geschiedenis en oudheidkunde, 4de reeks, 6de deel, 's Gravenhage, 1907, p. 7-66. Zie p. 25-30.

(192) „Dats te weten, dat alle die coepscepe van Campen, die die Mase zoeken, striken zullen ene werven st jaers tusschen die viirboet ende den Zvarten Wael ende haer viirboetghelt brenghen binnen der stede van den Briele ende betalen den viirboetmeysters... Vort est te weten, dat elc cogghe es sculdich ache grote ende elc yver vier grote of payment daer ieghens ende al ander scepe daerna als si sculdich zien van rechte. Vort zo en zullen wi, noch onze nacomelinghe der stede van Campen, dit vorghenoemde ghelt niet meerren...". Höhlbaum, H.U.B., dl. II, p. 161, nr. 384 .

(193) „dat wi... met den vierboetmeisters over een gedragen sijn, dese vierboeten op te brengene, te makene ende te houdene op der scepe cost, die hier voermaels met den vierboeten cost gedaen hebben. Ende om dat alle scepen, die de Maze zoeken, in geenre manieren der vierboeten ombaren en mogen, zo hebben wi narentstelike bevolen ende bevelen dese vierboeten op te brengene sonder merren ende van elken scepen, dat uute onsen lande vaert, also vele gelts te nemene, alze den vierboetmeysters goed dencken zal dese vierboeten mede op te brengene, te makene ende te houdene ende dit ghelt te minderne ende te meerne, alze dickewile als $t$ 
Mechtilt, vrouwe van Voorne. In 1358 maakte ze bekend dat ze op eigen kosten tot het laten leggen in de inkom van de Maas van vier drijvende tonnen of boeien had doen overgaan. Voortaan evenwel zou, naast het kaap- en vuurboetgeld, ook tonnengeld geheven worden, namelijk 21 groten per schip, hetzij kogge, ever of hulk, met een draagvermogen van minstens 60 last, dat geladen uit zee komend de Maas zou binnenvaren, en 14 groten per kleinere eenheid. Deze bijdrage was tijdelijk aan de rentmeester te betalen ${ }^{194}$. Naderhand blijkt het ganse signalisatiestelsel bestaande uit de vuutbakens en de tonnen met de daaraan verbonden gelden samengevoegd en onder één beheer gesteld te zijn, namelijk dat van de stad Brielle. Deze zag zich begin 1390 door Aelbrecht, graaf van Holland en Zeeland, voorgoed in het bezit van dit beheer met heffingen gesteld, alhoewel onder beding van de medezeggenschap of inspraak van de betrokken varende kooplui en onder voorbehoud van ieders recht, waaronder ook de vorstelijke en stedelijke prerogatieven. Deze regeling, die aan het geschil betreffende het recht tot heffing van bakengelden een einde stelde, was eindelijk mogelijk geworden doordat graaf Aelbrecht ook de heer van Voorne en Brielle was. Opvallend in de desbetreffende akte is het gebruik van de uitdrukking "vierende capen" in de betekenis van landmerken, die tegelijk als vuurboeten dienden. Samen met de drijvende tonnen vormden deze dus van 1358 af in de inkom van de Maas één signalisatieketen ten behoeve vooral van de stroomopwaarts gelegen havens. Door de overname van dit bakenstelsel door de stad Brielle waren de twee vuurboeten van parochiaal gemeentelijk geworden. Als gevolg daarvan was ook aan het autonoom beheer van de twee vuurbakens door de, ,viirboetmeysters" een einde gekomen ${ }^{195}$. Dank zij archeologische opsporingen en aanduidingen op oude landkaarten weten we waar de beide Brielse vuurboeten stonden, namelijk buiten de stad aan de kust van Oost-Voorne ${ }^{196}$.

Dat de stad Brielle sinds de overname van de beide ,vierboeten" voor het onderhoud van die bakens en ook voor dit van de drijvende tonnen

orbaer ende noet es. Ende dit ghelt geven elc stierman $t$ enden zier teelt sonder enich verdrach ende hebben... die vierboetmeysters... machtich gemaekt dit ghelt in te panden, alze men hier voermaels gedaen heeft... ende gouden die panden min, dan die stierman sculdich ware, dat zoude men an den stierman verhalen. Ware oec, dat men geene panden tote des stiermans en vonde, so soude men $t$ scip ende $t$ gewande pande, dat die stierman gevoert hadde...". Van Alkemade en Van der Schelling, dl. II, p. 22, nr. XXXII.

(194) De oorkonde bepaalde verder dat ,wat manne die Maze in coemt, die zal siin tonneghelt gheven in allen manieren ende rechte, als men vierboetghelt innet ende betaelt". Höhlbaum, H.U.B., dl. III, p. 188-189, nr. 414, oorkonde van 8 sept. 1358. - Van enige samenvoeging van de nieuwe heffing en het vuurboetgeld is er in het stuk geen sprake. Eigenlijk was de beslissing het resultaat van een overeenkomst met de hanzeaten en de stad Dordrecht.

(195) ,dat wy bevolen hebben ende bevelen... onser stede van den Briele te bewaren (de) vierende capen, die nu ter tyt op ter Maze staen of namels staen sullen, op horen coste ende daer zullen si weder of hebben alle profyt, dat daer of coemt. Ende dit zullen si doen bi rade den ghemenen coepman, behoudeliken ons, ende onsen ghemenen steden en den ghemenen coepman hoers rechts". Van Alkemade en Van der Schelling, dl. II, p. 48, nr. XLIX.

(196) C. Hoek, De (Briellese) vuurbakens ter beveiliging van de scheepvaart in de middeleeuwen, in Rotterdams Jaarboekje, 1965, p. 254-264, zie p. 260-261. 
instond en, als gevolg daarvan, de opbrengst van het vuurbaken- en tonnengeld mocht opstrijken, blijkt uit de oudste rekening van die gemeente of beter uit het deel ervan, dat in afschrift bewaard gebleven is. Uit deze stadsrekening, waarvan het boekjaar over de periode, gaande van 1 oktober 1415 tot en met 30 september 1416, liep, leren we dat de twee betrokken vuurbakens respektievelijk ,die hoge vierboete" en "die lage vierboete” geheten werden. Waarschijnlijk waren ze allebei, afgezien van de grondvesten en de vuurhaarden, in hout gebouwd en hadden ze dus elk het voorkomen van een houten toren of staketsel met een gebinte bestaande uit balken en planken. Het ligt voor de hand dat dit houtwerk, evenals het metselwerk van de haarden, nu en dan hersteld of zelfs gedeeltelijk, zoniet volledig, vernieuwd diende te worden. De uitgaven in verband daarmede vinden we in genoemde stadsrekening opgesomd, evenals die betreffende de aankoop van brandstof als riet, glei, turf en hout en de wedden van de vier stokers over de dertien maanden, dat ze toen 's nachts het vuur in de beide vierboeten onderhouden hadden. In het totaal bedroegen deze onkosten, waarbij inbegrepen die aan de tonnen besteed, bijna 164 pond Hollands ${ }^{197}$. Daartegenover stond een ontvangst aan kaap- en vuurboetgeld van iets meer dan 140 pond in dezelfde punt ${ }^{198}$. Soortgelijke gegevens vinden we verder in de volgende stadsrekeningen, die voor een groot deel en wel hoofdzakelijk van 1453 af bewaard bleven ${ }^{199}$. Voor het

(197) „Dits die cost van den vierboeten in reecke te houden. Item, gegeven van 6 middelhouten..., van 16 keperhouten..., van 8 tachters..., van 6 eycken planken..., van 400 steens, dair die haerden op die vierboeten of ghemaects (sijn)... Item, van dubbel kokerspikeren, kokerspikeren (sic), boeyspikeren ende ijseren bouten, die an beide vierboeten verbesicht sijn... Item, gegeven Martijn ende Reyngen van 5 dage, die sij elcs tymerden an die hoge vierboeten ende van 2 dage, die sij tymerden an die lage vierboete... Summa... 15 lb. 9 s. 10 d. Hollants".

„Dits den cost van den vierboeten te vueren ende van den stokers. Item, gegeven Coppijn Casus, dat hij gelevert heeft riet, gluey, turf ende hout, dair men op die vierbouten gheviert heeft van Bamisse tot Onser Vrouwen lichtmisse... $24 \mathrm{lb}$. Hollants. Item, gegeven Pieter die Naeyer, dat hij gelevert heeft riet, gluey, turf ende hout, die men op die vierboeten gheviert heeft van Onsser Vrouwen lichtmisse lestleden tot Bamisse dairan naest commende... $28 \mathrm{lb} .13 \mathrm{~s}$. 4 d. Hollands. Item, gegeven (den) 4 stokers, dat sij 13 maenden lang nachts gestooct hebben op die vierboeten, tot elker maent onder hen vieren $6 \mathrm{lb}$. Hollants, maect $78 \mathrm{lb}$. Hollants. Item, gegeven den zelven voir haer pilsen $8 \mathrm{lb}$. Hollants. Item, gegeven den zelven tot vijf hoochtiden, tot elker hoochtijt onder hem vieren 20 gr., maect 3 b. 6 s. 8 d. Hollants. Summa $142 \mathrm{lb}$. Hollants, den Yngelsen nobel gerekent voir 92 grooten, maict, den zelven nobel gherekent voir 80 grooten, 122 lb. 3 s. 5 d. Hollants". Ib., p. 256-257, uittreksel uit de stadsrek. 1415-1416, f ${ }^{\circ}$ 17-18, maar zonder verdere bronvermelding. - De uitgaven voor het onderhoud en het leggen van de drijvende tonnen bedroegen samen 16 lb. 6 s. 4 d. Hollands. Ib., p. 257-258, f $f^{\circ} 16$ van de rekening. - Zie n. 199.

(198) „Dits ontfangen van capen ende vierboeten. Item... van den eersten halven jare, dat verscheen op Onsser Liever Vrouwendach te lichtmisse... 75 lb. 14 s. 4 d. Hollants. Item, ontfangen... van den lesten halven jare (dat) verscheen op Sinte Jacops apostelsdach verleden... $64 \mathrm{lb} .13 \mathrm{~s} .7$ d. Hollants. Summa $140 \mathrm{lb} .7 \mathrm{~s} .10 \mathrm{~d}$. Hollants". Ibidem, p. 255-256, naar f $\mathrm{f}^{\circ} 5$ van de rekening.

(199) Van vier van de oudste stadsrekeningen, namelijk die over de boekjaren 1413-1414, 1415-1416, 1418-1419 en 1423-1424, bleven alleen afschriften van uittreksels bewaard, vooral in de ,,informaties" van 1521 en 1527 , die in 1565 , op last van de schepenen van Brielle, overgeschreven werden en aldus in een handschrift 
overige komen in de gemeentelijke verordeningen van Brielle ook enkele bepalingen voor in verband met de betaling van de kaap-, voorboet- en tonnengelden. Aan de inning van deze bijdragen dienden volgens dergelijke ordonnantie van vóor 1445 de loodsen hun medewerking te verlenen 200 . De heffing zelf was meestal in handen van een pachter.

In de Brielse stadsrekeningen uit de tweede helft van de 15 de eeuw staan heel wat bijzonderheden over het onderhoud van de beide vuurbakens en de bezigheden van de "vierboeters" of stokers. Uit de posten daarover in de stadsrekening over het boekjaar 1453-1454 zou afgeleid kunnen worden, dat de beide vuurbakens toen steeds in hout waren met uitzondering natuurlijk van hun haarden. Overigens werd tijdens dat boekjaar bovenop een van de twee bakens en dan blijkbaar bovenop de "lage vierboete" een mast voorzien van een klokvormig vlechtwerk in een met pik of teer bestreken zeildoek geplaatst om als teken over dag te fungeren ${ }^{201}$. Eerst in de rekening over het ambtsjaar 1459-1460 is er sprake van ,die steenen vierboete" met haar haard en haar ,groete vierpanne". Toen werd in de overblijvende ,houten vierboete” ook een ijzeren "lanteerne" voor het branden van een kaarsvuur aangebracht. Daarvoor werden heel wat kaarsen aangekocht'202. Vooral de stenen haarden, waarin het

bewaard bleven. Van Alkemade en Van der Schelling, dl. I, p. 363. - S.P. Haak, p. 8. - Voor het overige zijn daar nog de stadsrekeningen over de boekjaren of uit de periodes $1417-1418,1453-1460,1462-1470$ en $1475-1480$ voor wat de 15 de eeuw betreft. Daarna komen eerst van 1533 af opnieuw bewaarde stadsrekeningen voor en dan nog met soms belangrijke lacunes. Brielle, Stadsarchief, thesaurie-rekeningen. We bedanken de heer stadsarchivaris van Brielle voor de informatie, die hij ons daarover verstrekte.

(200) ,Van hoe een leydtsager varen op $t$ Mase. Item, en sal gheen leidsager varen op die Mase om scepen te nemen te gheleden, eer die scippere off die coepman op $t$ lant gecomen is in sijns waerts huys ende eer hy sijn caepgelt ende vierboetgelt betailt heeft. Ende so wie dat anders dede, dat wair op een boete van 3 pont Hollans. Ende gheen leitsagher en sal gheen scip nemen te geleden, hy en heeft oirloff genomen van den burgermeisters ende litteyken gebrocht, dattet vierboetgelt ende caepgelt betaelt is...". H. De Jager, De middeleeuwsche keuren der stad Briele, in Oude Vaderlandsche Rechtsbronnen (Werken der Vereeniging tot uitgave der bronnen van het oude vaderlandsche recht, gevestigd te Utrecht), 2 de reeks, nr. 2. 's Gravenhage, 1901, p. 180. - „Leydtsager” : loods.

(201) Een timmerman met zijn twee knechten werkte gedurende 12 dagen, an die cape ende vierboete". Daarbij verwerkte hij heel wat ,rachters" (balken of palen), ,waghescot” (gezaagd eikenhout), ,barkoenen" (rondhout of palen), „middelhout" (bindbalken), ijzeren bouten en spijkers, waaronder ,dubbelde kokerspikeren" en "lasijsers". De korf diende naar omhoog te worden gehesen met strengen in "weebast". Het benodigde hout en het gereedschap of alaam van de drie timmerlui waren per schip aangevoerd en daarna tot „onder die vierboeten" gebracht geworden. Na afloop van de werken, werd wat overschoot van het hout in het vaartuig terug ingeladen. Brielle, S.A., Stadsrekening 1453-1454, f $22 \mathrm{v}^{\circ}$.

(202) "Item, ghegheven Jan die Slotemaker van die vierpanne al nyeu te maken, sonder den bodem, op die houten vierboete, 3 s., ende vermaect op die steenen vierboete die groete vierpanne al nyeu, sonder den bodem, 4 s. Item, ghegeven 2 man van 6 daghen werkens an een nyeu dore op die houten vierboete ende an den haert ende an den nyeuwen lantaern, dair men nu mede viert, huerlijc $6 \mathrm{gr}$. sdaechs...". Ib., rek. 1459-1460, fo $24 \mathrm{v}^{\circ}$ en vlg. - Hoek, p. 258. - Voor de lantaarn, die eerst in de loop van 1460 tijdelijk in gebruik genomen werd, waren tijdens het boekjaar 1460-1461 490 pond kaarsen aangekocht en verbruikt geworden. Het ambts- 
nachtelijk vuur onderhouden werd, dienden elk jaar hersteld of vernieuwd te worden. De twee ,vierboeters", die tegen een vooraf met de stad overeengekomen loon werkten, stookten jaarlijks in de twee vuurbakens slechts van april tot december of uitzonderlijk vanaf januari ${ }^{203}$. Ze gebruikten daartoe hetzij riet, hetzij turf, hetzij blokken brandhout ${ }^{204}$. Om deze brandstof naar boven in de vuurboet te halen, beschikten ze over enkele manden en repen. Bovendien hadden ze permanent de beschikking over twee tonnen, gevuld met water, blijkbaar een ton per baken en dit waarschijnlijk ter bestrijding van een mogelijk begin van brand in het houtwerk of om het smeulend vuur in de haarden te blussen ${ }^{205}$.

In 1465 werd, door een stedelijke verordening, vrijstelling van betaling van het ,capegelt", ,vierboetegelt" en ,tonnengelt" verleend aan de stuurlui en schippers van vaartuigen herkomstig uit havens of plaatsen, waar zich, zoals te Brielle, twee vuurbakens bevonden en waar de Briellenaren eveneens van zulke bijdragen vrijgesteld waren ${ }^{206}$. Hier volgt dan het tarief van deze bijdragen met ernaast tussen haakjes de verhogingen ingevoerd in 1498, telkens berekend in "groten" 207 :

\begin{tabular}{|c|c|c|c|}
\hline Aard van de beffing & $\begin{array}{l}\text { Schepen van } 60 \\
\text { last of meer }\end{array}$ & $\begin{array}{c}\text { Schepen van minder } \\
\text { dan } 60 \text { last tot } \\
32 \text { last }\end{array}$ & $\begin{array}{c}\text { Schepen van minder } \\
\text { dan } 32 \text { last }\end{array}$ \\
\hline „Capegelt" & 4 s. (5 s.) & 32 d. $(3$ s. 4 d. $)$ & $16 \mathrm{~d} .(20 \mathrm{~d})$. \\
\hline "Vierboetgelt" & 20 d. (3 s.) & 20 d. (3 s.) & 20 d. (3 s.) \\
\hline "Tonnegelt" & 12 d. (2 s.) & 9 d. $(18$ d. $)$ & 6 d. (9 d.) \\
\hline
\end{tabular}

jaar voordien had men met oude touwen en met teer 1000 toortsen gemaakt, wat er zou kunnen op wijzen, dat die voor het geven van seinen gediend hadden ter vervanging van genoemde lantaarn. Ib., rek. 1459-1460, f $25 \mathrm{r}^{\circ}$, en rek. 1460-1461, f $28 \mathrm{r}^{\circ}-29 \mathrm{r}^{\circ}$.

(203) Op te merken is, dat het aantal weken vóór en na de winter, tijdens dewelke de nachtelijke vuren ontstoken en onderhouden werden, voor alle boekjaren niet identiek was, dit wellicht als gevolg van de veranderlijke omstandigheden. Het desbetreffende aantal weken bedroeg tijdens het boekjaar 1453-1454: 8 en 32, tijdens het boekjaar 1459-1460: 8 en 25 en tijdens het daaropvolgend boekjaar : 10 en 25. Ib., rek. 1453-1454, fo $22 \mathrm{r}^{\circ}$; rek. 1459-1460, fo $24 \mathrm{v}^{\circ}-25 \mathrm{r}^{\circ}$ en rek. $1560-$ $1561, f^{\circ} 28 r^{\circ}$.

(204) Riet gedurende het boekjaar 1453-1454, turf en houtblokken tijdens de boekjaren 1459-1460 en 1460-1461. Ibidem.

(205) Aankoop van twee tonnen om water in te zetten: boekjaar 1453-1454. Aankoop van manden en repen: boekjaar 1460-1461. Ibidem.

(206) De genoemde gelden was men verschuldigd, uutgedaen die scepen, die thuys horen ten steden, havenen ofte plaetsen, daer twee vierboeten staen ende daer onse ingesetenen vry zijn". Nota gevoegd bij een afschrift van de stedelijke ordonnantie van 12 mei 1465 betreffende het tarief van genoemde heffingen. De Jager, p. $175-176$, n. 1 .

(207) Tekst van de „ordinancie van den caepgelde ende vierboetgelde” en van de daaraan aangebrachte aanvullingen of wijzigingen, naar de oorspronkelijke keure en een aanvullend afschrift ervan van 12 mei 1465, in De Jager, p. 174-175. - Tekst van de ,ordonnantie van den Hove van Holland, aangaande het zeetonnen-, en kaapen vierboetgeld op 't inkommen van de Maas" van 3 aug. 1498, in Van Alkemade en Van der Schelling, dl. II, p. 119, nr. XCVII. - Nieuwe tariefverhoging in 1578. Ib., p. 189, nr. CXVIII. 
De drie heffingen samen op de haringbuizen bedroegen per buis jaarlijks 3 s. (4 s.).

De verhoging van het tarief van het vuurboetgeld en de twee andere gelden, was, naar het besluit van het Hof van Holland dienaangaande, noodzakelijk om te verhelpen aan de verwaarlozing van het signalisatiestelsel in de inkom van de Maas en aan het verlies van schepen, goederen en mensenlevens als gevolg daarvan. De bedoeling van de genomen maatregel was door een hogere opbrengst van de genoemde rechten de goede werking van de signalisatie nabij Brielle te herstellen en in stand te houden ${ }^{208}$. De toepassing van het verhoogd tarief leverde evenwel niet volledig het resultaat op dat men ervan verwacht had en wel wegens de ontduiking door sommige voorbijvarende schippers en kooplui van de betaling van de verschuldigde rechten. Deze laatsten oordeelden klaarblijkelijk niet zonder reden dat het boeienstelsel nog geen voldoening gaf. Dit verklaart dan ook de uitvaardiging op 12 februari 1517 door koning Karel, de latere keizer, en het Hof van Holland, daarin voorgelicht door de Hollandse havensteden, van een ordonnantie nopens de juiste plaatsing en het onderhoud van de drijvende tonnen, de oprichting van nieuwe staande tekens en de bestraffing met een boete van degenen, die na zouden laten de verschuldigde bakengelden te betalen. De nieuwe verordening stelde evenwel voortaan de stad Brielle aansprakelijk voor het degelijk onderhoud van het ganse stelsel van bakens en boeien, waarover ze samen met het Land van Voorne het beheer had ${ }^{209}$. Alle moeilijkheden inzake de interpretatie en toepassing van de reglementen waren daarmee nochtans niet uit de weg geruimd. Betwistingen rezen inderdaad weldra in verband met

(208) „Omme te voorzien up tie ongeregeltheit, die zy by die onderhoudenisse van den zeetonnen, cape ende vierboet, up 't incommen van den Maze, dat te niete gegaen es mitten soberen loen, dat, omme die onderhoudenisse van den zelven tot noch toe betaelt es, ende daer by veel scepen ende cooplieden deser landen in lyve ende goederen verdorven zijn...". Ib., p. 119.

(209) ,Alzoeveel ende diversche clachten... gecommen zyn van diversche schipperen ende coopluiden, zoe wel van onsen landen, als oick van vreemde luiden, frequenterende ende versouckende onsen landen van Hollandt ende Zeelandt uut der zee de Maeze incommende ende die zelve weder uut varende, overmits dat zy seiden, dat de cape, vierboete, zeetonnen ende baken in den Maese zeer qualicken onderhouden ende bewaert zyn geweest, dair van die van onser stede van den Brielle in den Lande van Voirne $t$ bewint, administratie ende toesicht altyts gehadt hebben... daeromme up die voorseide saecke doen hoeren die van onser steden van Dordrecht, Delft, Goude, Rotterdam, Schiedam, Vlaerdinge ende andere, die de voirseide materie angaen mochte, ende oick mede die voirseide van der stede van den Brielle... die zeiden meest alle de voirseide gebreecken toegecommen te zyn deur quade betalinge van den schipperen ende coopvairders, de voirseide Maze uut ende invarende, uut welke vele verdervinge van schepen, luiden, coopmanschappen ende andere inconvenienten commen mochten. Soe ist, dat wy... ordonneren ende verclaren mits desen, dat de voirseide van onse stede van den Brielle... maecken ende onderhouden sullen capen, vierboeten ende vier zeetonnen... Ende... dat alle schepen, zo wel coopvaerders, buissen, palinckschepen, als alle andere, de Maeze uut ende invaerende, gehouden sullen wesen te betalen... Ende als van den schepen, die van ouds plagen te betaelen in $t$ uit seilen, sullen gehouden zyn te betaelen, al eer zy voirby de voirseide stede van den Brielle vaeren sullen... uutgeseidt die haringbuissen, ten harinck vaerende, sullen betaelen voir de theelt...". Ib., p. 125-128, nr. C, tekst van de ordonnantie. 
de houding van sommige Rotterdamse binnenschippers, die gewoon waren de Maas- en kustwateren te bevaren, zonder naar een vreemd land over te steken, tenzij uitzonderlijk, en daarom weigerachtig stonden tegenover de betaling van de voor hun kleine vaartuigen verschuldigde vuurboet- en andere bakengelden, te meer daar tijdens de wintermaanden, gedurende dewelke ze ook uitvoeren, de signalisatie grotendeels uitviel. Na een proces dienaangaande, gevoerd tussen de stad Brielle en een viertal weerspannige schippers, zagen laatstgenoemden zich door een arrest van het Hof van Holland van 20 januari 1527 weliswaar van de betaling van de signalisatiegelden voor hun binnenlandse reizen vrijgesteld, maar, voor wat hun buitenlandse reizen betrof toch tot de vereffening van die gelden veroordeeld ${ }^{210}$. Uit hetzelfde arrest vernemen we dat de signalisatie in de inkom van de Maas nabij Brielle slechts volledig tijdens de periodes mei-eind november functioneerde, wat er blijkbaar op neerkwam, dat gedurende de wintermaanden, van december tot en met april, de drijvende tonnen weggehaald waren, maar de beide vuurboeten soms in werking bleven ${ }^{211}$. De regeling door het Hof van Holland getroffen had voor gevolg dat voortaan bijna alle binnenschippers, palingvangers en kustvaarders tegenover de betaling van de voor hun bootjes verschuldigde signalisatierechten erg weigerachtig stonden. Daarover had volgens de Brielse stadsrekening over het dienstjaar 1534-1535 de toenmalige bewaker van de vuurboeten en andere bakens, een zekere Aert Gherryts, een smid van beroep, zich dan ook te beklagen. Deze laatste had op zeker ogenblik inderdaad, blijkbaar na aanbesteding, aangenomen tegen een jaarlijkse vergoeding van 16 pond, gedurende veertien jaar, voor het onderhoud van het vuur in de

(210) „ende hoewel d impetranten ... niet gerechticht en waren omme yet van den ... gedaichden te mogen eisschen, ter cause ... als schipluiden van cleine schepen ... die hoor reisen meest doen binnen $s$ landts, hoewel zyluiden somtyts ende zeer zelden naer Sinte Katharynen ontrent Purificatie Marie, een reise mogen doen uuten Maze, maer meest passeren voor by Vlissingen tot in den riviere ofte in Engelandt ende dat al buiten tyden van den capen, vierboeten of uutlegginge der tonnen, immers, als die upgehouden waren, zulcks dat d impetranten voor den ... gedaichden geen cost of moeite en deden of en hadden ende oick gemerckt dat die gedaichden ende hare voorsaten althoes vry gevaren hadden...". Op grond van de ordonnantie van 1517 werden de met hun naam genoemde gedaagden veroordeeld ,te betalen den impetranten ... van alle die reisen, die sy gedaen hebben, die Maze uut ende in mit hueden, coggeschepen of anderen schepen, varende mit smackzeilen of anders, over zee, buiten s keisers lande van herwerts over", maar vrijgesteld ,van den eisch van den impetranten, aengaende die reisen, die zyluiden... gedaen moegen hebben, die Maze uut of in" met dezelfde vaartuigen. Ib., p. 157 161 , nr. CV, tekst van het vonnis. - Voor soortgelijke uitspraak op 9 sep., zie dl. I, p. 35 , nr. XIX.

(211) ,dat in $t$ jaer 1498 gemaect was een ordonnantie, inhoudende hoe ende in wat manieren $d$ impetranten onderhouden souden die capen, vierboeten, zeetonnen ende diergelycke up zekeren tydt van jaren daer toe dienende ende meest bequaem wesende, te weten van mey maent of, tot Katharinen dach, daer aen volgende tot preservatie van den grooten schepen, als hulcken, buisen, palinck schepen ende diergelyke, in ende uut gaten van der zee varende geduurende den voorseide tydt...". Ib., dl. II, p. 158, nr. CV, oorkonde van 1527. - In de ordonnantie van 1498 wordt er evenwel betreffende de periode tijdens dewelke het signalisatiestelsel jaarlijks door de stad Brielle onderhouden diende te worden, niets gezegd. Ib., p. 199, nr. XCVII. 
twee vuurboeten en het leggen van de drijvende tonnen in te staan. Tijdens genoemde periode zou hij alle onkosten van dat onderhoud en van de herstellingen aan de bakens te dragen hebben, maar mocht hij ook de opbrengst van de signalisatiegelden opstrijken. Als gevolg van zijn beklag over de insolventie van de schippers van de kleine vaartuigen, gaf de gemeente Brielle hem dat zelfde ambtsjaar, als vergoeding, nog de som van een pond ${ }^{212}$.

Dank zij de nog overgebleven Brielse stadsrekeningen uit de 16de eeuw kunnen we het wedervaren van de beide vuurboeten op Oost-Voorne verder volgen. In 1542, toen de steeds opnieuw opflakkerende oorlog tussen keizer Karel en de koning van Frankrijk, Frans I, een gevaarlijke wending begon aan te nemen, besliste het Hof van Holland de twee vuurbakens van Brielle buiten werking te stellen. De houten vuurboete werd zelfs volledig afgebroken en gesloopt. Daar ook de drijvende tonnen uit de Maasmonding weggehaald geworden waren, werd aldaar door de stad Brielle een wachtdienst van enkele loodsen ingesteld, ten einde de uitvarende Waterlandse haringbuizen te konvooieren en andere vaartuigen, die zouden willen uitzeilen, te waarschuwen. Midden 1544, na het einde van de vijandelijkheden, werd tot de wederopbouw van de houten vuurboete op een andere plaats, dan die waar ze vroeger stond, overgegaan. Daartoe won de gemeente Brielle het advies van Delft, Rotterdam, Schiedam en Delfshaven, die aan de grote visserij deelnamen, in. De stenen vuurboete, waarvan het houtwerk van de trappen en zolders hersteld en het dak vernieuwd geworden was, werd evenals de nieuwe houten vuurbaak, die bovenaan een ,huysken" had, nog hetzelfde jaar terug in bedrijf gesteld. Nieuw was ook dat voortaan in de haarden van de beide bakens steenkolen gestookt werden, waarvan men het vuur met blaasbalgen aanwakkerde. Van 17 september tot 25 november 1544, tijdens de haringteelt, zorgden aldus vier stokers voor het onderhoud van de nachtelijke vuurhaarden. In de Brielse stadsrekening over dat dienstjaar staan dan ook al de onkosten gedaan voor het terug in gebruik nemen van de beide bakens, het leggen van nieuwe drijvende tonnen en de reizen, ondernomen om van de Staten van Holland terugbetaling van de daartoe door de schepenen voorgeschoten gelden te bekomen, aangetekend ${ }^{213}$. Uit de volgende stadsrekeningen vernemen we dat de kolen voor de twee vuur-

(212) „Deselve Aert zou claeche, dat hy van de palickschepen ende smackezeylen qualyck betaelt worde". Volgens de overeenkomst van de aanneming kwam de opbrengst van hetgeen de ,buysen en coopvaerders" als signalisatiegeld betaalden hem toe. A.A. Arkenbout, De bakens van de Maasmond in de jaren 1534-1548, in Rotterdams Jaarboekje, 1960, p. 114-122, naar de stadstekeningen. Zie p. 114. Brielle, S.A., stadsrekening, boekjaar okt. 1534 - sept. 1535. - Eerst van het boekjaar 1533-1534 af bleven de Brielse stadstekeningen uit de 16de eeuw, alhoewel met sommige lacunes, bewaard.

(213) Arkenbout, p. 114-120, naar de Brielse stadsrekeningen over de boekjaren 1532-1543, 1543-1544 en 1544-1545, met een uittreksel uit de stadsrekening boekjaar okt. 1543 - sept. 1544. - H.C. Hazewinkel, Een zeldzame prent van J.C. Philips, in Rotterdams Jaarboekje, 1936, p. 55-64. Zie p. 58-59. - Hoek, p. 258-259. - Brielle, S.A., stadsrekeningen over genoemde boekjaren. - Ibidem, Memoriaelbouck I, jaren 1544 en 1545. - Van der Veen, p. 18. 
boeten meestal te Dordrecht aangekocht werden. Toen was men er reeds toe gekomen jaarlijks gedurende ongeveer 120 dagen tot in november en daarnaast, ten behoeve van de vissers op terugkeer van de winterkampagne, nog een paar nachten in december de vuren te laten branden ${ }^{214}$.

In het begin van het jaar 1552, na de hervatting van de oorlog tussen Karel $\mathrm{V}$ en de Franse koning, toenmaals Hendrik II, werden de twee Brielse vuurbakens opnieuw buiten bedrijf gesteld. Meer zelfs, de stenen vuurboet werd volledig afgebroken, wat overigens ook met de torens van de burcht, een gedeelte van de ringmuur en de bovenbouw van de kerk te Brielle gebeurde en dit om de vijand van uit zee alle zicht op mogelijke landmerken op Oost-Voorne te ontnemen. Reeds in oktober van hetzelfde jaar nochtans werd de houten vuurboet opnieuw in bedrijf genomen en het vuur van het verdwenen stenen baken door het licht van een kaarslantaarn vervangen. Een enkele wachter volstond toen voor de zorg over beide bakens ${ }^{215}$. In 1559, na de beëindiging van de oorlog, ging de gemeente Brielle tot de oprichting van een nieuwe stenen „vierboete" over, maar dan op een andere plaats, dan die waar de vroegere toren gestaan had. In februari van dat jaar was de houten vuurboet in de vlammen opgegaan. Ze werd evenwel een maand later op een andere plek terug opgericht, nadat ze van grondvesten in steen voorzien geworden was. Dit gebeurde in overleg met de havensteden Delft, Rotterdam en Schiedam ${ }^{216}$. Als gevolg van de uitbarsting van de opstand van de gezamenlijke Nederlanden tegen de Spaanse verdrukking in 1568, zouden niet lang daarna de twee Brielse vuurbakens opnieuw afgebroken worden. Eerst in 1593 kwamen de Gekommiteerde Raden van Holland, op aandringen van het overlegorgaan van de Grote Visserij, er toe de beide bakens te laten herbouwen, maar dan in hout. De twee nieuwe houten ,vierboetes" kwamen inderdaad tot stand, maar dienden in het vervolg, wegens vernietiging door brand

(214) Nog steeds waren het vier stokers, meer bepaald twee in elke ,vierboete", die voor het onderhoud van het nachtelijk vuur instonden. De ,wintervaert" of reis van de ,winterteelt" werd met ,houckbooten" gedaan. Van het in werking stellen van de beide "vierboetes" voor de van deze kampagne terugkerende vaartuigen is er sprake op 17 december 1544 en 26, evenals 28 december 1545. Hazewinkel, p. 59. - Arkenbout, p. 121. - Brielle, S.A., Memoriaelbouck, I, onder genoemde data.

(215) Deze ene vuurtorenwachter had aangenomen in ,de houte cape te vieren ende in de lanternen de kaersen te stellen ende de toesicht te hebben, dat ze de geheelen nacht duer barnen, welcke lanternen staen sal in de stede van de steene cape". Hazewinkel, p. 59-60. - Resolutiën van de Staten van Holland, o.m. onder de datum 6 oktober 1552. - De Brielse stadsrekeningen uit de tijdspanne 1548-1557 ontbreken. - Van der Veen, p. 18.

(216) Hoek, p. 259-262 en afbeelding 62, tonende de nog bestaande fundering van de oudste stenen, ,vierboete", waarvan de romp in 1552 afgebroken en naderhand niet meer weder opgebouwd zou worden. Het gebouw zelf blijkt achthoekig geweest te zijn en zijn hoogte, kuip en naald of kap samen zou zowat 30 meter bedragen hebben. Het telde drie verdiepingen met vloeren en zolders in hout. Op afbeelding 61 zijn de beide Brielse vuurbakens van vóór 1552 te zien. - De in 1559 opgerichte stenen, „vierboete" was in vierkant gebouwd. Elke zijde mat ongeveer 5 meter. Voor zijn bouw werden zowat 56500 stenen, voortkomend van de afbraak van de burcht op Oost-Voorne gebruikt. Hanzewinkel, p. 60-61. - Brielle, SA, stadsrekeningen over de boekjaren $1557-1558$ en 1558-1559. - Id., Memoriaelbouck I, onder de data 10 en 28 febr., 14 maart en 28 juli 1559 en 24 jan. 1562. 
of storm, soms terug opgericht, hersteld of verplaatst te worden. Pas in 1631 werd door de stad Brielle besloten, ter vervanging van een door brand vernietigde houten toren, een nieuwe stenen, ,vierboete" te laten bouwen. Deze staat, alhoewel erg beschadigd, heden nog steeds overeind 217 .

Westwaarts van Brielle, op de Zeeuwse eilanden, bevonden zich nog enkele ,vierboetes" en ook kapen of staande tekens. Tussen 1437 en 1451 zou de vuurboet van Goederede op het eiland van die naam opgericht geworden zijn ${ }^{218}$. In 1355 was reeds, op kosten van Zierikzee, op het eiland Schouwen een landteken tot stand gekomen, voor wiens onderhoud de schippers, die er op voeren, een ,teykengeld" te betalen hadden ${ }^{219}$. Ten slotte was daar ook nog de „vierboete" van het Zeeuwse Westkapelle op het eiland Walcheren, opgericht in 1370 of daaromtrent ${ }^{220}$. Dit baken sloot aan bij de keten van de vuurbakens aan de Vlaamse kust.

\section{De vuurbakens van de Zuidoostengelse kust van Great Yarmouth tot Dover}

Dat er van oudsher ten behoeve van de scheepvaart aan de zuidkust van Engeland vuren ontstoken werden, staat vast. In 1159 of daaromtrent weet de Engelse scholasticus Johannes van Salisbury ons te berichten, dat men, in zijn tijd, tot beveiliging van de zeevarenden voor de talrijke gevaren, die hen op zee bedreigden, zich zowel van optische, als van akoestische middelen bediende. Hij schrijft inderdaad daarover aldus : „vuren werden ontstoken, alarmkreten geslaakt en staande tekens opgericht, opdat de draaikolk van Scylla, de maalstroom van Charybdis, de onzichtbare riffen en de uitgestrekte zandige Syrten door de schepelingen op heilzame wijze gemeden zouden kunnen worden" ${ }^{221}$. Het is duidelijk

(217) Hazewinkel, p. 61-64 en afbeeldingen 9, 10 en 11: de Brielse vuurbakens in de $17 \mathrm{de}$ en 18de eeuw. Op afbeelding 12: de stenen vuurboet van 1631: huidige toestand. - Van der Veen, p. 19.

(218) A. W. Lang, Entwicklung, Aufbatw und Verwaltung des Seezeicbenwesens an der deutschen Noordseeküste bis zur Mitte des 19. Jabrbunderts. Bonn, 1965, p. 53 en 131, n. 327, naar een mededeling van de hr Kok, archivaris te Brielle. R. Van der Veen, p. 19: na 1552 werd op de kerktoren een kolenvuur als vuurbaken onderhouden.

(219) W.F. Verhoeven, Historiscbe tijd en oordeelkundige aanteekeningen op dezelve, 1774, p. 97. - Van der Veen, p. 17.

(220) In genoemd jaar beval Albrecht van Beyeren, graaf van Zeeland en Holland, de oprichting van het baken : „om vier te barnen op die vierboete te West Cappel, om stadiglick vier te branden van dezen tyd... Ieder schip, dat tusschen Wulpen en $t$ Veergat inkomen zullen, zal betalen tot onderhoud van vier ende menschen". Deze vuurboet stortte in 1398 in. Ze mocht evenwel van de vorst op kosten van de opbrengst van het strandgoed, dat plaatselijk aanspoelde, opnieuw opgericht worden, wat naderhand blijkbaar ook gebeurd moet zijn. K. Baart, Westkapelle en bare bevolking. Middelburg, 1889, p. 22-23. - Na 1470 fungeerde de kerktoren als baken. - Van der Veen, p. 17.

(221) „Accenduntur ignes, clamores excitantur, eriguntur et signa, quibus Cillea vorogo, turbo Caribdis, saxa latentia, tractus et tenacitas Sirtium a navigantibus queant salubriter declinari". Ioannis Saresberiensis Policraticus. Lib. 8, prologus. Uitg. Webb, dl II, p. 226. - Patrologia Latina, uitg. Migne, dl CXCIX, kol. 709 c. W. Vogel, Geschichte der deutschen Seeschiffabrt, Berlijn, 1915, dl I, p. 529. 
dat Johannes van Salisbury met deze aanhalingen over de beide verraderlijke rotshoogten aan weerskanten van de straat van Messina en de twee ondiepe golven aan de noordkust van Afrika het eigenlijk over de kusten van het Kanaal en het Nauw van Kales had. Uit zijn getuigenis is jammer genoeg niet af te leiden welke personen of instanties zich met de door hem beschreven rudimentaire en okkazionele vorm van hulpbetoon aan de zeevarenden inlieten. Wat er ook van zij, belangrijk is de door hem gebruikte terminologie, die we naderhand nog lang in Engeland aantreffen. Hij heeft het immers over "ignes" en ,signa”.

In de loop van de tweede helft van de 13 de eeuw vernemen we voor het eerst wat meer over de ontsteking van vuren of de oprichting van vuurbakens aan de oevers van het zuidwestelijk Noordzeegebied en wel in verband met de haringvangst, die aldaar jaarlijks meer bepaald vóór de kust van Zuidoost Engeland en in het bijzonder voor die van Norfolk van eind september tot begin november plaatsgreep. Na 1200 ontwikkelde de havenstad Yarmouth, aan de monding van de Yare, zich snel tot het centrum van dit zeevisserijbedrijf en tot haringmarkt, die ieder jaar veel vissers en kooplui aantrok. Onder deze zeelui, bevonden zich niet alleen vissers van Yarmouth zelf en Norfolk, maar ook lieden van de Cinque Ports, de bond van havensteden aan de kust van Kent en Sussex, bestaande, vanaf de regering van Richard Leeuwenhart, uit zeven gemeenten of plaatsen, namelijk Hastings, Winchelsea, Rye, Romney, Hythe, Dover en Sandwich, verbond dat blijkbaar bij de Romeinse traditie aansloot ${ }^{222}$. In ruil voor de levering van schepen en militaire dienst op zee hadden deze havenplaatsen van de Engelse koningen een afzonderlijk rechtsstatuut en uitgebreide voorrechten verkregen, waaronder tolvrijdom, vrijstelling van belasting, een speciale vertegenwoordiging door baronnen in het parlement, een eigen hof van justitie, een lokale wetgeving en een eigen admiraliteit. Deze laatste was inzake jurisdictie bevoegd voor de ganse kust tussen Seaford in Sussex en de Theemsmonding in Essex. De vissers van de bond mochten van oudsher aan de kust van Norfolk, meer bepaald in de streek van Yarmouth, vrij gebruik van de duinen en het strand maken, o.a. voor het drogen van hun netten, en bovendien hadden ze

(222) De Romeinse havens van Brittannië aan de straat van Dover waren Anderida (Pevensey), Portus Lemanis (Lympne), Portus Dubris (Dover), Rutupiae (Richborough) en Reculbium (Reculver). Volgens de „Notitia dignitatum" van 428 maakten deze vijf havens deel uit van de versterkte zone of "Litus Saxonicum", die het land tegen de oprukkende Saksen diende te beschermen. In deze zone lagen verder Othona (Bradwell), Gariannonum (Burgh Castle, aan de monding van de Yare), en Branodunum (Brancaster, aan de Wash). Van de militaire en maritieme organisatie aan de zuidoostkust van Engeland in het Romeins tijdperk moet minstens een zekere herinnering levendig gebleven zijn, althans in de streek zelf. De hoogste gezagdrager van de Cinque Ports, namelijk de „Lord Warden”, verkreeg immers de investituur van zijn ambt te Dover, zittend op een stuk muur, de "Braydenstone", een overblijfsel van de vroegere Romeinse westelijke toren. De la Roncière, dl. I, p. 62-63. - E. Janssens, Histoire de la Mer du Nord, Brussel, 1943 , p. 51 en 67-68. - V.-J. Vaillant, Classis Britannica, classis Samarica, cobors I Morinorum. Recberches d'épigrapbie et de numismatique. Arras, 1888, p. 317-318, met twee voorbeelden van de ceremonie op Braydenstone Hill, respectievelijk in 1694 en 1709 . 
er het recht vrij over hun vangsten te beschikken. Het kan dan ook niet verwonderen indien de baronnen van de Cinque Ports na de oprichting van de jaarmarkt te Yarmouth in 1208 eisten dat hun baljuws er tijdens het veertigtal dagen van de jaarlijkse duur van die foor, namelijk van 29 september tot 10 november, van de vierschaar zouden mogen deel uitmaken en er aan de kust voor de vuurbakens zouden moeten instaan, wat hen vergund werd ${ }^{223}$. Dit gaf evenwel aanleiding tot aanhoudende geschillen met de lieden van Great Yarmouth en Norfolk zelf. De Engelse koning, Edward I, poogde daaraan door zijn edikt van 20 mei 1277 een einde te stellen. Hij erkende inderdaad uitdrukkelijk het tweeledig karakter van het foorgerecht te Great Yarmouth en bevestigde de voorrechten van de Cinque Ports aldaar, waaronder ook het tijdelijk gebruik van „duin en strand", maar dan met de verplichting er tijdens de jaarmarkt ten behoeve van de scheepvaart de nachtelijke vuren aan te leggen en te onderhouden. De baljuws van de batonnen van de genoemde havens mochten evenwel, als vergoeding voor deze laatste dienst, van de stuurlui, die ervan profiteerden, een baken- of vuurgeld eisen, namelijk de ,fire pence", ten bedrage van twee penningen per boot. Het koninklijk edikt stipuleerde verder, dat in geval de baljuws van de baronnen van de Cinque Ports, aanwezig of niet te Great Yarmouth, nalieten de nachtelijke vuren aan te leggen of in stand te houden, de provoost van de stad dit mocht doen en het vuurbakengeld van de stuurlui in ontvangst mocht nemen ${ }^{224}$. De toepassing van deze schikkingen kunnen vanaf 1282 in de ,borough court rolls" of rekeningen van de rechtbank van Great Yarmouth nagegaan worden. In deze rekeningen, waarvan het boekjaar telkens op Sint-Michielsdag of 29 september begon, staan inderdaad tot 1371-'72 meestal de namen van de baljuws van de Cinque Ports en van hun sergeanten, die aan de zittingen van het foorgerecht te Great Yarmouth deelgenomen hadden, met de afbeelding van de merken door hen als bewijs van kwijting van het vuurgeld gebruikt, opgetekend ${ }^{225}$. Soms verwaarloosden de genoemde baljuws de ontsteking en het onderhoud van de nachtelijke vuren, alhoewel ze op de gerechtszittingen te Great Yarmouth aanwezig waren. Aan dergelijk

(223) A.E. Bradley, England's Outpost, the Country of the Kentish Cinque Ports, Londen, 1921. - K. Murray, The constitutional bistory of the Cinque Ports. Londen, 1935 .

(224) „En drayt de deniers, qe nos barons des porz demauundent au fu sustenir, volons et dioms, qe avanntdiz bailifs as barons des porz receivent e eyent les deus deniers des nefs costumiers, ke sunt apelez fire penys a fuis sustenir en les lus acoustumez pour seurte de la rivage des nefs untauntre taunt comme il vodrunt le feus sustenir et $\mathrm{s}$ il aveigne $\mathrm{k}$ il defaillent en la sustendance des feuz avantdiz, list a nostre prevost de Gernemue les deniers avauntdiz recevire e les feuz sustenir en la furme avantdite". London, Public Record Office, C 66/96/00143. In de rand: "Dictum regis inter barones de portibus et homines de Magna Gernemuthe". Jeakes, Charters of the Cinque Ports, 1728, p. 13-14. - H. Swinden, History and Antiquities of Great Yarmouth. Yarmouth, 1772, p. 194-197. - Handlist of the archives of Great Yarmouth Corporation of date before 1835. Uitgave 1965, p. 3. Royal charter, $n^{\circ}$ 2. De term "Great Yarmouth" dagtekent van \pm 1250.

(225) Handlist, o.c., p. 9-10. - Great Yarmouth, Town Archives, Borough Court Roll, nr. 4 (ambtsjaar 1282-1283) en volgende rollen te Norwich in het Norfolk Record Office. 
verzuim weet men het vergaan in de nacht van 28 oktober 1296 van het vaartuig "la Constance" en de dood van zijn bemanning van twintig koppen toe. Ook het jaar nadien zou dergelijk ongeval zich voorgedaan hebben ${ }^{226}$. In 1297 toen het op zee tussen de lieden van de Cinque Ports en die van Great Yarmouth tot een bloedig treffen gekomen was, evenals het daaropvolgende jaar gaven de baljuws van de baronnen van genoemd stedenverbond op de rechtbank van de jaarmarkt verstek, zodat klaarblijkelijk toen geen vuurbakens onderhouden werden ${ }^{227}$. In 1299, wegens het uitblijven op deze gerechtszittingen van de baljuws van Hithe en Romney, besloot de gerechtelijke overheid van Great Yarmouth zelf voor de vuren van het haringseizoen te zorgen ${ }^{228}$. De normale gang van zaken werd in het begin van de 14de eeuw hersteld, alhoewel het in 1303 tussen de baljuws van de Cinque Ports zelf tot een betwisting nopens het aantal en de toewijzing aan elk van de steden van het verbond van de te gebruiken merktekens $\mathrm{kwam}^{229}$. Nopens de aard en de standplaats van de vuurbakens aan de kust van Norfolk tijdens de periode van de jaarmarkt te Great Yarmouth worden we door de ",borough court rolls" van die stad weinig of niet ingelicht. Zeker is het dat er te Caister-on-Sea, ten noorden van Great Yarmouth, vuren ontstoken werden, zoals ook elders nabij die laatste havenstad ${ }^{230}$. De vuurhaarden zelf waren blijkbaar op

(226) „In anno xxxiij (1295) ballivi Quinque Portuum existentes in nundinis Jernemue defecerunt in sustentacione focorum, per quod navis Nicholai le Porter de Jernemue, que vocabatur la Constance cum xx hominibus periclitasset nocte apostolorum Simonis et Jude (28 okt.) anno predicto ante portum Jernemue". Londen, Public Record Office. Assize Roll 945, rot. 5. - Nog een ander vaartuig, de „Jonette", met 24 man aan boord, zou aldaar in de nacht van Allerheiligen ( 2 nov.) 1296 vergaan zijn. Ib. - Salzman, English trade, p. 225.

(227) Swinden, p. 181-182. Naamlijsten van de baljuws van de Cinque Ports, die met hun sergeanten op de rechtszittingen te Great Yarmouth verschenen waren, vanaf 1285, naar de gegevens voorkomend in de Borough Court Rolls. Voor de jaren 1297 en 1298 ontbreken deze gegevens in genoemde rollen.

(228) „Ballivus de Romen Hale et ballivus de Hethe non venerunt ad faciendum regale justicium, nec ad sustinendum focos pro marinellis et navibus piscatoribus, sicut debent. Ideo ballivi Jernemuthenses ceperunt predictos focos in manus suos pro collecta $2 \mathrm{~d}$. focos sustinendi, sicut continetur in dicto domini regis...". Norwich, Norfolk Record Office, Y/C4/21, nr. 4 R (1299-1300). De baljuws van de vijf andere havensteden waren wel verschenen. Toch daagden nadien ook die van Hithe nog op. - Swinden, p. 182.

(229) Nadat de baljuws van Hithe, Dover en Hastings voor hen zelf drie merktekens aangenomen hadden, ,venit Johannes Spicer, ballivus de Romene, et dicit, quod ipse habere quartum signum, set omnes alii ballivi de quinque portubus hoc noluerunt concedere, ideo nichil inde factum est". Swinden, p. 184. - Norwich, N.R.O., $\mathrm{Y} / \mathrm{C} 4$ / 26, nr. $4 \mathrm{R}$ (1303-1304). - In 1303 zou het dus, na de eis van de baljuw van Romney om ook een merkteken toegewezen te krijgen en de weigering van de andere baljuws daarop in te gaan, bij drie merktekens gebleven zijn.

(230) Op 11 november 1282 bevestigde een zekere Johannes Herny uit Caister-onSea, in eigen naam en in die van zijn vennoten, van de baljuws van Hithe kwijtschelding verkregen te hebben van hetgeen ze tot op die dag ,pro foco apud Castre sustinendo" verschuldigd gebleven waren. Norwich, N.R.O., Y / C 4 / 4, m. 4 R (1282-1283), getuigenis afgelegd vóór de Borough Court of rechtbank van de jaarmarkt te Great Yarmouth. J. Herny was dus waarschijnlijk de stuurman van een vissersboot. - Swinden, p. 196, voetnoot. - Op te merken valt dat de etymologische betekenis van de plaatsnaam Caister ",castrum", d.i. Romeins kamp of fort, is. - 
een hoogte aangebracht. De term ,vierberg”, waarmede te Kales en Brielle oorspronkelijk zulke vuurbakens aangeduid werden, zou daarop kunnen wijzen ${ }^{231}$. Voor het overige weten we dat in 1261 de baronnen van Winchelsea, een van de steden van de Cinque Ports, voor de duur van twee jaar, van de Engelse koning de toelating ontvingen, als bijdrage voor het onderhoud van het nachtelijk licht van een "luminare" of lantaarn in de inkom van die haven, van elk vaartuig, geladen met goederen, dat er kwam binnenvaren, een vuurgeld ten bedrage van twee penningen te eisen. Dit gebeurde evenwel onder voorbehoud, dat ze niet van oudsher de gewoonte gehad zouden hebben of verplicht geweest waren, op eigen kosten, voor dit licht of vuur te zorgen ${ }^{232}$. Deze laatste stipulatie laat wellicht toe te veronderstellen, dat ook in de andere havens, behorende tot de Cinque Ports of toch sommige onder hen, door de plaatselijke baronnen voor het onderhoud van een havenlantaarn of een andere soort vuurbaken, ten behoeve van de aankomende schepen, ingestaan werd. Dat was ongetwijfeld zo te Dover, de voornaamste haven van genoemd stedenverbond, bovendien gelegen vlak bij Canterbury, bedevaartplaats en zetel van de primaat van Engeland. De overtocht naar dat land vanuit de kust van westelijk Vlaanderen en Artezie richtte zich toen nog steeds meestal naar Dover of omgeving. Of de Romeinse pharus te Dover toen nog in bedrijf was, is niet geweten. Wel wordt in 1201 melding gemaakt van een zekere Rannulfus, bijgenaamd of betiteld „phararius”, d.i. houder of bewaker van de genoemde toren, en dat jaar op zeker ogenblik belast met de opdracht aan de Benediktijner prior te Dover een rechtelijke dagvaarding te gaan overhandigen ${ }^{233}$. De benaming ,phararius” zou misschien kunnen betekenen, dat Rannulfus, als houder van de ,pharus", er tevens ook voor het nachtelijk vuur diende in te staan, maar daarover vernemen we niets.

Ging de ontsteking van de nachtelijke of militaire vuren te Caister-on-Sea en aan de monding van de Yare soms terug op de Romeinse tradities aldaar? Zie n. 222.

(231) In 1371 dienden op koninklijk bevel in Sussex op de heuvels wachtvuren ontstoken en onderhouden te worden: „Ad aliquod signum commune per ignem super montes vel alio modo... fieri faciendum, per quod homines patrie illius, si periculum aliquod ex hujusmodi hostium aggressibus imineat, poterunt congruo termino premuniri". Londen, P.R.O., Patent Roll 45, Ed. III pl. I m. 18 d. (Sussex).

(232) „Henticus, omnibus etc. salutem. Sciatis nos concessisse dilectis nobis baronibus de Winchilse, quod de qualibet navi, applicante in portu de Winchilse mercimoniis carcate, capiant duos denarios ad sustentationem suam (lees : fuam) cuidam luminaris, quod habent in portu suo ad indempnitate et salvationem nautarum in portu predicto noctante applicantium, nisi barones predicti luminare illud sumptibus suis sustentare debeant et consueverint, in cuidam tempore durante a festo purificationis beate Marie anno regni XLV usque ad finem duorum annorum proximo sequentem. Datum et supra". In de marge: „pro baronibus de Winchilse”. Patent Roll of Rot. Patent, 45 Henry III. Londen, P.R.O., C 66 / 16 / 00143. - Calendar of Patent Rolls, 1258-1266, p. 140, onder de datum 30 jan. 1261 (45ste jaar van de regering van Hendrik III van Engeland). - Met „fuam” werd blijkbaar "feu” bedoeld.

(233) „Kent. De itinere Ricardi de Heriet. Dies datus est priori de Dovre per Rannulfum Phararium et Stephano de Cnardintone in octabis sancti Yllarii ad recipiendum cirographum suum". Curia Regis Rolls (H.M.S.O.), dl. II, p. 43. - Het hoofd van de Priory of St. Mary the Virgin and of St. Martin in 1201 was Felix de Rosa. C.R. Haines, Dover Priory, Cambridge University Press, 1930. 
Belangrijk nochtans is het verder gebruik van de term ,pharus”, wat uit de uitdrukking ,phararius" afgeleid kan worden en wat zeker op het voortbestaan van de oude toren als dusdanig sloeg. Deze laatste maakte toen sinds kort deel uit van de burcht van Dover op Castle Hill, wat niet noodzakelijk een beletsel voor zijn verdere werking als "pharus” moet geweest zijn ${ }^{234}$. Omstreeks 1540 vond de Engelse kroniekschrijver Leland het gebouw echter bouwvallig en buiten gebruik ${ }^{235}$. Op het einde van de $16 \mathrm{de}$ eeuw koesterde men toch nog het plan tot oprichting op de gevaarlijke Goodwin Sands, de zandbank vóór de kust van Kent aan het Nauw van Kales, van een vuurbaken. Daarvan kwam evenwel niets terecht, daar de indiener van het projekt voor diens uitvoering van de koninklijke schatkist een te hoge subsidie eiste ${ }^{236}$. De vuurbakens op de kust van Norfolk nabij de haven van Great Yarmouth waren toen nog meestal in werking ${ }^{237}$.

\section{De Middeleeuwse vuurbakens in bet Westeuropees perspectief}

De Grieks-Romeinse vuurtorentraditie in de landen gelegen aan de Middellandse Zee stierf na 400 met de ineenstorting van het Westromeinse keizerrijk niet uit. Ze werd er immers door de opvolgers van de Romeinen, namelijk de Byzantijnen of Grieken van het Oostromeinse rijk, en de Arabieren voortgezet. Het eeuwenlang voortbestaan van deze traditie was ongetwijfeld niet zonder belang voor de oprichting in de loop van de middeleeuwen van nieuwe vuurbakens overal waar zich de behoefte eraan deed gevoelen, maar dan vooral in de Middellandse Zee zelf vanaf de kruistochten aldaar. De Noorditaliaanse havensteden, waaronder Genua, Pisa en Venetië begonnen inderdaad, dank zij de handelsbedrijvigheid, die met deze christelijke overzeese expedities naar het nabije Oosten gepaard ging, economisch, politiek en matitiem snel op te komen en een van de middelen om hun groeiende scheepvaart te beveiligen bestond in het onderhoud van vuurbakens. De ,farus" van Genua wordt voor het eerst in 1161 vermeld, maar hij bestond al vroeger. Naderhand bekend onder de veelzeggende naam ,Lanterna”, bevond hij zich op de kaap of „capo di Faro", waar hij blijkbaar van de oudste stedelijke wallen deel uitmaakte.

(234) J. Puckle, The Church and Tower of Dover Castle. Dover, 1880, p. 51. Het kasteel lag 375 voet boven de zeespiegel. Wel was de afstand tot de haven nogal groot.

(235) Hij meldt daarover: ,on the toppe of the hye clive... a ruine of a tower, which hath been as a pharos of a mark to shypes on the se". Stevenson, p. 21-22.

(236) De initiatiefnemer, Gowen Smith, eiste, in ruil voor de oprichting van een „fyrme and staide beacon to shewe his fyre by night", van de koningin niets minder dan de betaling van 1.000 pond en de toelating, tot onderhoud van die vuurboet, van een tolheffing op de schepen. Ib., p. 23-24, zonder aanduiding van bron.

(237) „Quod nec ballivi ville Magne Jernemuthe, nec ballivi Quinque Portuum manutenuerunt et sustentaverunt ignem ad portum Jernemue, prout usitatans fuit ad magnum periculum subditorum domini regis... et navium suarum". Stuk dagtekenend uit het 20 ste jaar van de regering van koning Hendrik VIII, d.i. 1529. Swinden, p. 193. - Dat jaar had men dus uitzonderlijk nagelaten te Great Yarmouth de nachtelijke vuren te ontsteken. 
Het was een toren, op wiens top door de wachters ervan rooksignalen gegeven werden, aanvankelijk door middel van strovuur en later door de rook van brandende pek en teer. Over dag werden er ook met vlaggen seinen gegeven. Voor het gebruik van deze seingeving hadden de schippers overigens een vuurgeld te betalen ${ }^{238}$. De eerste vuurtoren van Pisa stond op het eilandje Meloria, vóót de Italiaanse kust, maar nogal ver van de monding van de Arno, waaraan die havenstad gelegen was. Opgericht omstreeks 1157, werd hij tijdens de oorlogen tussen de Genuezen en Pisanen meermaals verwoest, maar telkens terug opgebouwd, tot hij in 1304 door een nieuw gebouw op de geïsoleerde rotspunt te Livorno vervangen diende te worden. Leonardo da Vinci, de bekende Italiaanse schilder, tekende omstreeks 1500 deze hoge vuurtoren, benevens de andere hoge torens van Pisa. Tussen Genua en Pisa bevond zich ook nog de vuurtoren van Tino aan de golf van La Spezia, die zijn nut bewezen had in de strijd tegen de zeeroverij. Meer zuidwaarts, op de noordoostelijke uithoek van het eiland Sicilië, functioneerde in 1194 reeds de vuurtoren van Messina, aan de zeestraat van die naam. Daar was toen immers, zoals in de tijd van het Romeins rijk, het scheepvaartverkeer zeer druk. Elders moeten er aan de kusten van Italië, zowel in het westen, als in het oosten, in sommige aldaar gelegen haventjes, ook vuurbakens bestaan hebben, vermits men hun afbeeldingen in enkele Italiaanse kerken aldaar kan zien. Meestal gaat het dan om de voorstelling van de wonderbare redding van schipbreukelingen of zeevarenden in nood, na beroep op een of andere patroonheilige. Het verband tussen vuurbaken en godsdienst kwam in die tijd ook nog op andere wijzen tot uiting en niet het minst onder de vorm van een waarachtig dienstbetoon aan de zeelui. Te Venetië, de bloeiendste Noorditaliaanse handelsrepubliek, gelegen aan de noordkust van de Adriatische zee, gaf de stedelijke senaat in 1312 immers de toelating om op de toren van de Sint-Niklaaskerk een ,pharus" aan te brengen ${ }^{239}$.

Merkwaardig voor de technische en maritieme vernieuwing, die de kruistochten met zich medebrachten, was zeker de oprichting in 1246 door de Franse koning Lodewijk IX of de Heilige, aan de monding van de Petit Rhône, in het westen van de Rhônedelta, van een donjon, de ,tour de Constance", voorzien van een hoge ",farot" of vuurbaken. De genoemde vorst zette daarmee de stichting in van een eigen maritieme basis aan de kust van de Middellandse zee, van waaruit hij, zonder van de Italiaanse havens te moeten afhangen, op kruistocht zoul kunnen vertrekken, namelijk de nieuwe stad en handelsnederzetting Aigues-Mortes. Lodewijk IX vertrok inderdaad in 1248 en 1270 telkens met zijn vloot en strijdkrachten, waaronder ook Vlamingen, vanuit deze haven. De eerste maal ging zijn tocht naar Damiette in de delta van de Nijl voor de strijd tegen de sultan van Egypte en de tweede maal naar Tunis, waar hij, bij het beleg van de stad, aan de pest zou sterven. Filips II de Stoute, de

(238) Van de betaling van dat geld is er in 1161 reeds sprake: ,pro igne faciendo in capite fari". Stevenson, p. 18, zonder vermelding van bron.

(239) Ib., p. 18. - Enciclopedia Italiana di scienze, lettere ed arti. Treves, 1932, dl. XIV (ENO-FEO), p. 829-830, verbo „faro”. 
opvolger van de beroemde Franse koning, zette het werk van zijn voorganger te Aigues-Mortes voort. De opgekomen handelsnederzetting aldaar werd ommuurd. De vuurtoren, die daardoor buiten de wallen kwam te liggen, bleef verder in gebruik, maar voor zijn onderhoud werd voortaan van de schippers een vuurgeld ten bedrage van een penning per pond aan handelswaarde van de getransporteerde goederen gevraagd ${ }^{240}$.

De kennis van wat een "pharus" was en voor de nachtelijke scheepvaart betekende blijkt vooral zeer levendig te zijn gebleven in het oostelijk bekken van de Middellandse Zee, waar de Byzantijnen in hun bakens Grieks vuur als verlichting aanwendden en de Arabieken petroleumlantaarns in hun havens gebruikten. Overigens stond aldaar, in de Nijlmonding, nog steeds de oude "pharos" van Alexandrië overeind, althans tot 1326, ogenblik waarop hij als gevolg van een aardbeving in zou storten. Met even veel ontzag als naar dit antieke monument, moeten de kruisvaarders naar de "toren” of "phanar" van de Gouden Hoorn, de haven van Byzantium, het middeleeuwse Constantinopel, opgekeken hebben. $\mathrm{Na}$ de vierde kruistocht, waaraan de graaf van Vlaanderen, Boudewijn IX deelgenomen had, was deze wereldstad inderdaad gedurende meer dan een halve eeuw, namelijk van 1204 tot 1261, het centrum van een Frankisch, d.i. een Latijns-katholiek keizerrijk, bestuurd door westerlingen. De kruisvaarders, waaronder ook Vlamingen, die aan de tochten naar Palestina, Constantinopel, Egypte of Tunis meegedaan hadden, wisten ongetwijfeld, na hun terugkeer in eigen land, over al hetgeen ze in het betrokken mediterrane gebied gezien hadden, met daaronder ook de Romeinse, Italiaanse, Byzantijnse of oosterse vuurbakens een en ander te vertellen. Deze kennisgeving, naast het voortbestaan van de Romeinse torens te La Coruña, Bonen en Dover, droeg wellicht hier en daar, aan de kusten van de Atlantische Oceaan, de Noordzee en de Baltische zee, bij tot de oprichting van de middeleeuwse vuurbakens. Dit kan althans zo geweest zijn aan de Vlaamse kust, waar de herinnering aan de Romeinse vuurtorens zeer lang in stand moet gebleven zijn ${ }^{241}$.

De invloed en uitstraling van de Byzantijnse beschaving deed zich in de volle middeleeuwen nog verder gevoelen dan die van de Romeinse cultuur, namelijk zelfs tot in Oost- en Noord-Europa. Nog vóór de herleving van de economie in West-Europa en het ontstaan van het verbond van Duitse hanzesteden, bestond er in de Oostzee een bloeiende handel en scheepvaart, die aldaar aan de kusten aan vuur- en andere bakens behoefte had. Zo zou, volgens de kroniekschrijver Adam van Bremen, die in het midden van de 11 de eeuw leefde, in zijn tijd, op het eiland Wollin, aan de monding van de Oder, nabij de opkomende handelsnederzetting Jumne, zich een "olla Vulcani" of vulkaanoven bevonden hebben. Deze werd in de volksmond "Graecus ignis", d.i. Grieks vuur genoemd, waarmede dan een vuurhaard naar Byzantijns voorbeeld kan bedoeld geweest zijn.

(240) Ch. de la Roncière, dl. I, p. 165. - Pagezy, Mémoires sur le port d'AiguesMortes, Parijs, 1889 , p. 260. - Th. Luykx, De graven van Vlaanderen en de kruis. vaarten, Leuven 1947, p. 205 en vlg. Zie p. 219: kaartje.

(241) Zie n. 10 
Jumne was inderdaad in die tijd een trefpunt van Slaven, Grieken, Bar* baren, Saksen en andere buitenlandse kooplui in de Baltische zee ${ }^{242}$. Ook elders aan de kusten van deze zee blijkt, volgens archeologische gegevens, vuurbakens toen geen zeldzaamheid geweest te zijn ${ }^{243}$. Toch moeten we wachten tot de 13 de eeuw, met de opkomst van de Duitse hanzeverbonden, om aan de kusten van Noord-Duitsland, Schonen en de noordelijke Nederlanden duurzame landmerken of vuurbakens opgericht te zien worden en dit nagenoeg in dezelfde tijd als in Vlaanderen. Aldus ging koning Waldemar II van Denemarken, van wiens rijk toen ook Scanië of Schonen in Zuid-Zweden deel uitmaakte, omstreeks 1226 in op het verzoek van de Broeders van de orde van de Predikheren of Dominikanen, om ten behoeve van de scheepvaart op dit schierleiland, nabij de aldaar gelegen handelsnederzetting Falsterbo, een "signum" of landmerk in hout te mogen laten oprichten en het nodige materiaal daartoe ter plaatse uit de bossen te halen ${ }^{244}$. Nabij dit teken, dat zowel voor de haringvissers en de talrijke kooplui, die de haringmarkten van Falsterbo en Schonen kwamen aandoen, als voor degenen, die in of uit de Sont voeren, richtinggevend was, werd naderhand, op een heuvel, 's nachts een vuur ontstoken, wat wellicht aan een zogenaamde ,vierberg" of ,vierboete" ontstaan gaf ${ }^{245}$. In dezelfde Oostzee, maar dan aan de Noordduitse kust, aan de monding van de Trave, stroomafwaarts van Lübeck, wordt in 1226 het bestaan van een ander ,signum", evenals van een burcht, voor de beveiliging van de scheepvaart op die stroom vermeld. Genoemde hanzestad verkreeg dat jaar inderdaad door een keizerlijke oorkonde het bezit en het genot van beide, zonder dat we evenwel te weten komen, waarin het ,signum" bestond en of het van een vuurbaken voorzien was ${ }^{246}$. Wel vernemen we naderhand dat de stad Lübeck aan de Travemonding een

(242) „Ultra Leuticos, qui alio nomine Wilzi dicuntur, Oddara flumen occurit ditissimus amnis Sclavaniae regionis. In cuius ostio, qua Scyticas alluit paludes nobilissima civitas Iumne celeberrimam praestat stacionem barbaris et Graecis, qui sunt in circuitu... Ibi est Olla Vulcani, quod incolae Graecum ignem vocant, de quo etiam meminit Solinus". M. Adami gesta Hammaburgensis ecclesiae pontificum usque ad annum 1072. M.G.H., SS, IV, dl. 7, p. 312. - „Vulcanus": vuurberg. C.J. Solinus was een Romeins aardrijkskundige uit de 3 de eeuw na C., die het in zijn geschriften ook had over de Etna, als de heilige plaats toegewijd aan Volcanus, god van het vuur. - Ph. Dollinger, De Hanze, opkomst, bloei en ondergang van een bandelswerbond. Utrecht-Antwerpen, 1967 (Aulareeks nr. 308), p. 32.

(243) Naar opgravingen uitgewezen hebben, zou er ook te Birka, de bekende havenstad van de Noormannen in zuidoost Zweden, in de 9de en 10 de eeuw een vuurbaken in gebruik geweest zijn. D. Ellmers, Frübmittelalterlicbe Handelsscbiffabrt in Mittel- und Nordeuropa. Neumünster, 1972 (Schriften des Deutschen Schiffahrtmuseum Bremerhaven), p. 229, n. 752.

(244) "In Falsterbothe... signum aliquod discretivum pro vitando periculo navigantum". Höhlbaum, H.U.B., dl. I, p. 62, nr. 195, oorkonde van kort na 1225, ontleding.

(245) Vogel, dl. I, p. 529, en afbeelding 16, p. 237, kaartje met de lokalisatie van Skanör en Falsterbo op het schiereiland Schonen.

(246) „Fundum extra Travenemunde juxta portum, ubi signum ejusdem portus habetur..." Höhlbaum, H.U.B., dl. I, p. 64, nt. 205, oorkonde van juni 1226, ontleding. Voor de burg, zie p. 65 , nr. 206, stuk van dezelfde datum. Bekrachtiging van de beide voorrechten door een oorkonde van 22 december 1320. Ib., dl. II, p. 155, nr. 374 . 
„custos lucerne" of bewaker van de havenlantaarn in dienst had ${ }^{247}$. Deze "lucerna" doet overigens aan de „luminare" te Winchelsea denken. Typisch voor het kerkelijk, parochiaal of godsdienstig aspekt van het vuurbakenbeleid is het voorbeeld van Stralsund. Krachtens een oorkonde van 3 juli 1306, stond de Sint-Niklaasabdij van Hiddensee aan deze hansestad een stuk grond op het eiland Zingst voor de oprichting van een "lucerna" af, waarvoor in ruil de monniken de zorg over dit baken, dat alleen tijdens de periodes gaande van 8 september tot 1 mei zou functioneren, op zich namen. Dit stelde tevens de kloosterlingen in de mogelijkheid door het horen van biecht en het toedienen van andere sacramenten aan de zeevarenden aan zielzorg te doen ${ }^{248}$. Een andere belangrijke hanzestad, maar dan aan de Duitse Noordzeekust, die aan de oprichting van een landmerk met vuurbaken dacht, was Hamburg, dat, krachtens een privilegie in 1286 door de hertog van Saksen aan de gemeente verleend, een ,signum" en wel een „cum lumine perpetuo" mocht hebben 249. Dit teken, dat ten behoeve van de zeevarenden, die de Elbe in de richting van de stad wilden opvaren, ergens aan de monding van die stroom diende gebouwd te worden, blijkt maar een middel te zijn geweest voor de oprichting van een wacht- of slottoren. Dezelfde hanzestad verkreeg immers in 1299 van de toenmalige hertog van Saksen de toelating, als "signum" ter bescherming van degenen, die de Elbe op- of afvoeren, op het kustleiland "Nova O", een "opus", of "werc", een soort bolwerk, te bouwen "250. Dit uit steen of hout of uit beide materialen op te trekken gebouw, dat natuurlijk ook als versterking dienen moest, kwam inderdaad in het begin van de 14 de eeuw op genoemd eiland, dat voortaan Neuwerk of beter "Nieuwewerck" genoemd zou worden, tot stand. In tegenstelling tot het oorspronkelijk opzet, bezat het evenwel geen vast of bestendig licht, dat als vuurbaken diende ${ }^{251}$. Voor het overige kan de geschiedenis van de Hamburgse wachttoren als staand teken op het eiland Neuwerk de volgende eeuwen in grote trekken goed nagegaan worden. Feitelijk blijkt voor Hamburg de betonning van de Elbemonding belangrijker dan de oprichting en het onderhoud van vuurbakens aldaar geweest te zijn $2 \bar{s} 2$.

(247) Vogel, dl. I, p. 529, naar de Lubeckse "Kammereibuche", jaar 1316, in Lübeckisches Urkundenbuch. Lubeck, 1843 en vlg. jaren, dl. II, nr. 1086.

(248) Ib., dl. II, p. 40, nr. 91, ontleding van de oorkonde betreffende de "lucerna", en n. 2, zelfde bladzijde, uittreksel uit het stuk betreffende de zielezorg. - Vogel, dl. I, p. 529.

(249) Met de vergunning tot de oprichting van het baken lag de bedoeling voor „ut velificantes die noctuque notitiam habeant hujus loci". Höhlbaum, H.U.B., dl. I, p. 346, nr. 1002, ontleding van de desbetreffende oorkonde van 14 april 1286.

(250) „Primo, ut ipsi portus in signum et cognitionem omnibus Albiam ascendentibus ad ipsam civitatem Hamburgensem vel de eadem descendentibus in insula nova $\mathrm{O}$ dicta... opus werc proprie construant lapideum aut ligneum, altum, profundum, latum et amplum, sicut ipsis utile et expediens fuerit...". Ib., dl. II, p. 445, nr. 1323, stuk van 1 nov. 1299 .

(251) Ib., dl. II, p. 111, nr. 274, oorkonde van 1 april 1316, waarin sprake is van de ,turrim Nove Werc". Voor de financiële moeilijkheden, die zich in verband met de oprichting van de toren stelden, zie p. 57-58, nr. 137, stuk van 13 jan. 1309. - De constructie zou zowat tien jaar, van 1300 tot 1310, geduurd hebben.

(252) Nadat in 1374 het houten bovendeel van de toren door brand vernield ge- 
Betonning en opstelling van ,kapen” of staande tekens was aan de Hollandse kust met haar talrijke zeegaten zeker primerend. Minstens sinds het begin van de 14 de eeuw blijkt de stad Kampen zich met de betonning van het Vlie, het zeegat tussen Terschelling en Vlieland, en met het onderhoud van „kapen” op beide eilanden ingelaten te hebben ${ }^{253}$. Eerst in 1452 zoul Amsterdam, met de toestemming van Filips de Goede, hertog van Bourgondië, op zijn beurt overgaan tot de installatie van vier "kapen” respectievelijk op de eilanden Terschelling, Vlieland en Texel, alsmede te Huisduinen en tot het leggen in de zeegaten daartussen, toegang tot de Zuiderzee verlenend, van een zestigtal drijvende tonnen als boeien. Of in de beide gevallen Kampen en Amsterdam ook het recht of de verplichting verkregen hadden om eveneens nachtelijke vuren te ontsteken en vuurboetgeld te innen is niet duidelijk ${ }^{254}$. Wat er ook van zij, in de loop van de 15 de eeuw groeide het aantal vuurbakens aan de Hollandse kust en op de aanhorige eilanden aan. In een stuk van koning Filips II van 1568 worden ze opgesomd, namelijk die op Terschelling en Vlieland, die te Wijk aan Zee, Egmond aan Zee, Zandvoort, Noordwijk aan Zee, Scheveningen, Terheide en Brielle, benevens het baken op Goeree. Naderhand kwamen daarbij nog de vuurboeten te Huisduinen, Petten en Katwijk aan Zee, zonder te vergeten de Zeeuwse bakens, waaronder dit te Westkapelle ${ }^{255}$. De belangrijkste vuurbakens waren na 1593 die op Oost-Voorne, nabij Brielle. In $1594 \mathrm{kwam}$ op Terschelling ter vervanging van het oude baken met de naam Brandarius een toren, later Brandaris geheten, tot stand. Alhoewel hij bovenop van een platform met een plaats om hout te stoken voorzien was, bleef zijn uitrusting beperkt tot een lantaarn, zodat hij hoofdzakelijk als landmerk overdag diende. Pas in 1835 na tot een moderne vuurtoren te zijn verbouwd, werd de Brandaris als typisch

worden was, kwam men er toe het gebouw gans in steen te herbouwen. Vogel, dl. II, p. 529-530. - A. Lang, p. 34-35. - K. Ferber, Die Entwicklung des Hamburger Tonnen-, Baken- und Leuchtfeuerwesen, in Mitschrift des Vereins für bamb. Gescbichte, dl. 18, 1914.

(253) Overeenkomst tussen de stad Kampen en de gemeente op Terschelling voor de oprichting van ,eyn voerhuys of eyn marke", waarvan eerstgenoemde de uitgaven voor de levering van stenen en balken op zich zou nemen. Stuk van 28 sept. 1323. Afschrift. Kampen, Stadsarchief, Privilegieboek, $f^{\circ} 66 \mathrm{r}^{\circ}$. - Höhlbaum e.a., H.U.B., dl. II, p. 192, n. 1. - Zie ook d1. III, p. 188, n. 2. - "Voerhuys" : voorhuis, misschien te lezen ,vuerhuys". Van der Veen, p. 23.

(254) Door Amsterdam zouden opgericht worden vier staande tekens ,gheheeten kapen, dats te wetene een van den kapen op Huisdunen, $t$ ander op Texell, terde op Vlielant ende $t$ vierde op Ter Schelling" en in het water gelegd zowat 60 tonnen, waarvan het onderhoud door de heffing van een lastgeld bekostigd zou worden. Höhlbaum, d1. VIII, nr. 144, stuk van 16 mei 1452. - P. Scheltema, Inventaris van het Amsterdamsche arcbief. Amsterdam, 1866, dl. I, p. 68 . - In 1572 werd dit „paalkistrechtprivilegie" of recht om bakengeld te eisen aan de stad Enkhuizen overgedragen. Van der Veen, p. 22.

(255) Vissersvuren worden o.a. vermeld te Noordwijk aan Zee omstreeks 1444 en te Scheveningen omstreeks 1527. De vuurboet van Katwijk moet van vóór 1605 dagtekenen. De toren van Terheide, waarop tot ongeveer 1610 "gloy" gestookt werd en daarna steenkolen, moest in 1648 wegens onbruik gesloopt worden. Van der Veen, p. 19-24. - J.C. Vermaas, Geschiedenis van Scheveningen. Den Haag, 1926, dl. I, p. 268 en vlg. 


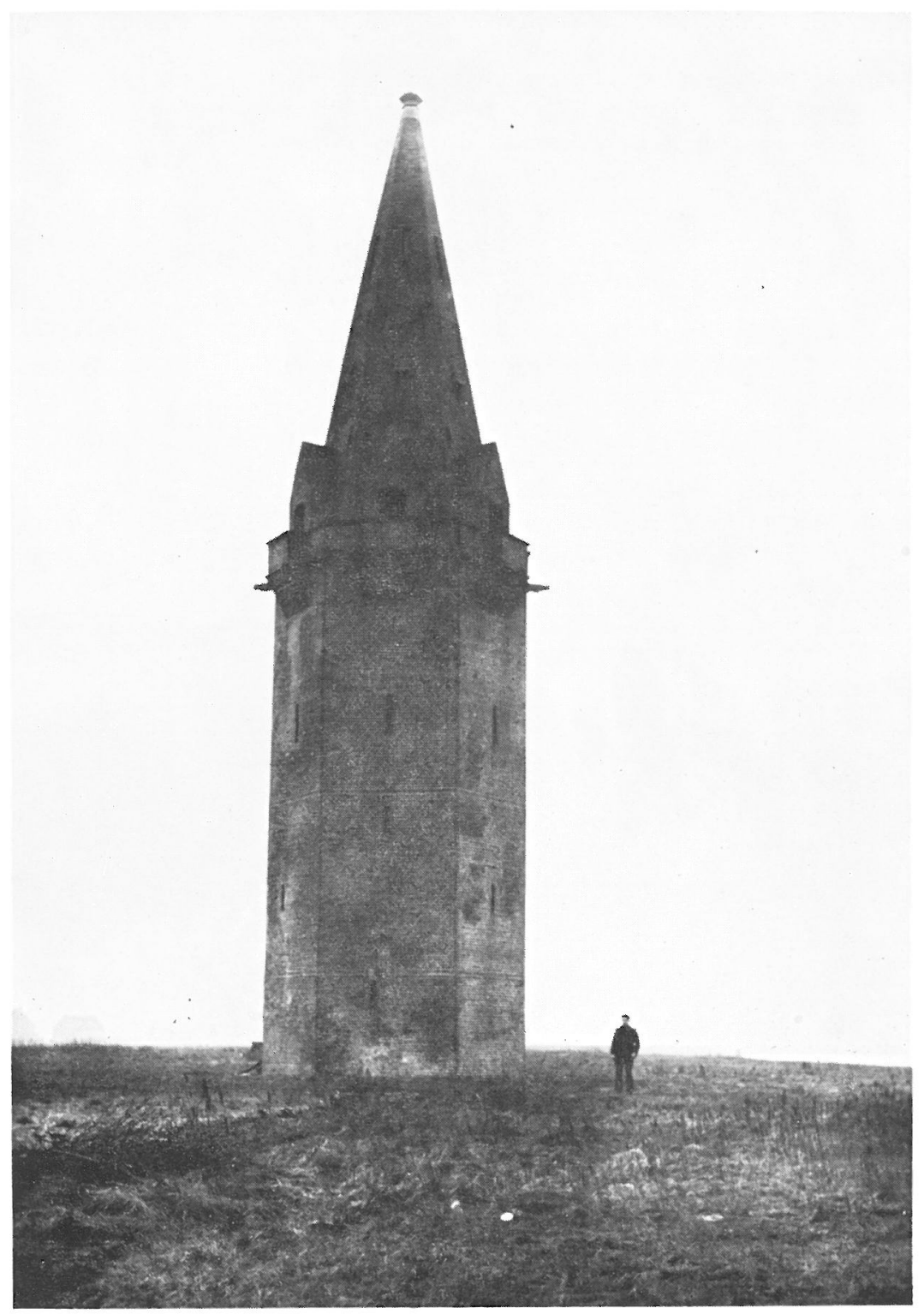

De ,groote vierboete" te Nieuwpoort omstreeks 1900 na haar laatste restauratie. Zo ongeveer moeten in de 16 de eeuw ook de ,vierboetes" van Oostende, Blankenberge en Heist er uitgezien hebben. - Cliché van vóór 1914. 


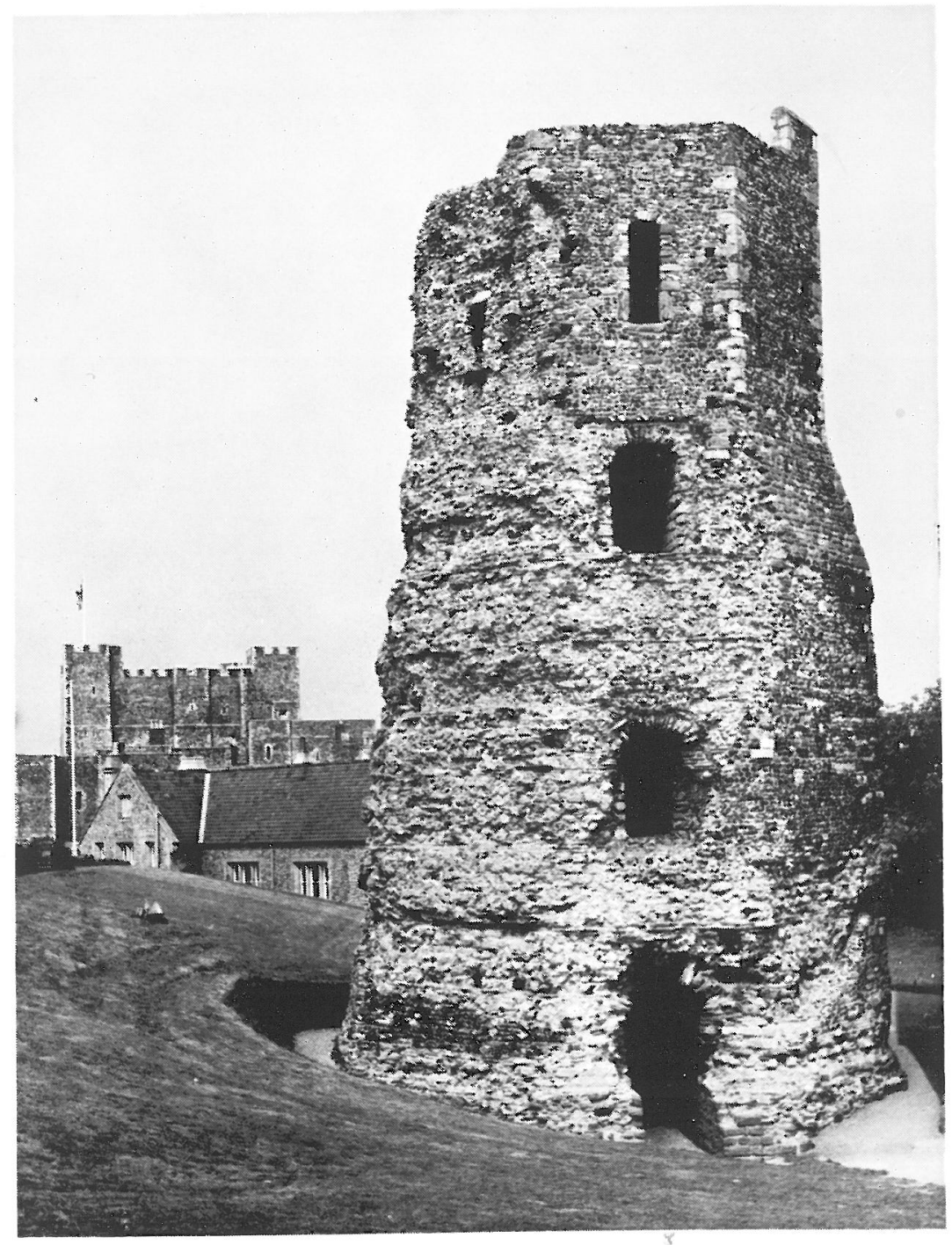

De antieke vuurtoren op Castle Hill te Dover, huidige toestand. Het achthoekige piramidale gebouw telt nog drie verdiepingen, waarvan de derde middeleeuws is, heeft een hoogte van 80 voet of ongeveer 26,5 meter en verheft zich op genoemde heuvel ongeveer 375 voet of 125 meter boven de zeespiegel. Foto: The charter trustees of the town of Dover. Clerk and treasurer: Cyril Fletcher. 
gebouw van die aard aan de Nederlandse kust zoveel als het symbool van de Hollandse kustverlichting ${ }^{256}$. Op te merken is dus dat nog vóór de scheiding tussen Noord en Zuid van het ontstaan van een keten van vuurbakens aan de kust van de Nederlanden gesproken kan worden.

Een soortgelijke ontwikkeling als aan de Hollandse-Zeeuwse kust vinden we aan de oevers van Oost-Engeland. Van een ,signum” of staand teken nabij de stad Grimsby aan de monding van de Humber, namelijk de „Blakeman”, reeds bestaand omstreeks 1200, wordt in een oorkonde van 1258 gewag gemaakt. Krachtens een koninklijke schenking werd de zorg over dit landmerk dat jaat aan de Sint-Leonarduskerk nabij Grimsby toevertrouwd. Deze mocht van de zeelui, die met hun vaartuigen de Humber opvoeren en Grimsby aandeden, voortaan een bakengeld vragen, waarvan het bedrag vast bepaald was ${ }^{257}$. Het kerkelijk of godsdienstig karakter van de dienstverlening aan de schippers aldaar, vinden we ook aan de linkeroever van de stroom, waar de havenstad Hull in opkomst was, maar dan veel later. In 1427 inderdaad was een kluizenaar, gehecht aan de kapel van Onze Lieve Vrouw en Sint-Anna te Ravenser Odd op Spurn Head, de kaap die ten noorden de inkom van de Humber beheerste, begonnen met de bouw van een toren, voorzien van een lichtbaken. De handelaars en zeelui van Hull, voor wie deze onderneming van belang was, verzochten toen de Engelse koning om financiële hulp voor dat project, wat ze verkregen onder de vorm van een tolheffing op de vaartuigen voor de duur van tien jaar ${ }^{258}$. Toch was het eerst vanaf de anglikaanse reformatie dat aan de Engelse kust de initiatieven tot de oprich-

(256) Tot 1593 bevond zich op het westelijk einde van Terschelling een oude kapel met toren, gewijd aan Sint Brandaan, vandaar dan de naam Brandarius of Brandaris. Tot op dat ogenblik was de toren nog steeds een ,,merck" en „baeck", door de stad Amsterdam onderhouden. Door een resolutie van de Staten van Holland en West-Friesland van januari 1593 werd besloten dat de oude toren, die op instorten stond en weldra door de zee overspoeld zou worden, door een andere „Brandariustoren" vervangen zou worden, maar dan gelegen meer oostwaarts en binnen de duinen, behoorlijk van hoogte en breedte en ", met eene plaetse booven om te vuren". Het nieuwe gebouw, dat, op kosten van genoemde Staten, door Amsterdam en Enkhuizen opgericht werd, stortte evenwel nog hetzelfde jaar, als gevolg van de overhaasting, waarmede men te werk gegaan was, in. Het volgend jaar begon men aan de wederopbouw ervan en in 1594 kon dan ook blijkbaar de definitieve toren in gebruik genomen worden. H. de Feyfer, De geschiedenis van de Brandaris. Zes eeuwen Brandaris, in Spiegel der Zeilvadrt, jg. I, nr. 1 (juli 1977). Unieboek, Bussum, p. 23-29, met afbeeldingen en kaarten.

(257) Calendar of Cbarter Rolls, dl. II, 43 Henri III, m. 5, ontleding van de oorkonde van 5 november 1258 dienaangaande.

(258) De kluizenaar, ,havvying compassion and pitee of the Cristen poeple, that ofte tymes are there perished... hath begunne, in weye of charite, in salvacion of Cristen poeple, godes and marchaundises comying into Humbre, to make a toure to be uppon day light a redy bekyn, wheryn shall be light gevyng by nyght, to alle the vesselx, that comyn into the seid ryver of Humbre". De ",mayor" van Hull ontving kort daarop van de koning de toelating om, tot onderhoud van de vuurtoren, gedurende tien jaar, van elk vaartuig een tol te eisen, berekend naar de tonnenmaat, namelijk 12 penningen per eenheid van 120 "tonnetite" en meer vaten, 8 penningen per eenheid met een draagvermogen tussen "de 120 en 100 vaten en 4 penningen per eenheid met een kleinere kapaciteit. Calendar of Patent Rolls, 1427, p. 457. - Rotula Parl., dl. IV, p. 364. - Stevenson, p. 21. - Salzman, p. 224. 
ting van licht- en vuurbakens toenamen. Zo zien we in 1540 de vissersen zeeluicorporatie Trinity House uit de havenstad Newcastle upon Tyne krachtens een privilegie, verkregen enkele jaren voordien, overgaan tot de oprichting te North Shields, nabij de noordelijke oever van de Tynemonding, van twee stenen torens, die weliswaar voor defensiedoeleinden bestemd waren, maar tevens ook als lichtbakens dienen moesten, aangezien ze elk met een kaarslantaarn uitgerust werden. De geschiedenis van deze beide bakens, waarvan er een in 1658-1659, in hout herbouwd werd, is voorts tot in de 19 de eeuw te volgen. Belangrijker dan de twee landmerken van North Shields was het kolenvuur, dat vanaf een bepaald ogenblik in de 16 de eeuw of misschien zelfs van oudsher op het kasteel van Tynemouth, eveneens aan de noordelijke over van de Tynemonding, 's nachts brandend gehouden werd, maar waarvan we pas in 1581 gewag horen maken. Deze vuurtoren blijkt de eerste van die aard aan de Engelse kust te zijn geweest ${ }^{259}$. Het was nochtans niet eerder dan in de loop van de 17 de eeuw dat we aan de Noordzeekust van Engeland, van Tynemouth tot kaap Dungeness ten westen van Dover, een doorlopende keten van lichtbakens zien tot stand komen. Weliswaar waren deze bakens oorspronkelijk alleen maar havenlantaarns. Daaronder behoorden ook de twee nieuwe houten torens met kaarslantaarns te Caister-on-Sea even ten noorden van Great Yarmouth ${ }^{260}$. Aan de andere Engelse kusten ging het nachtelijk dienstbetoon aan de zeevarenden meestal uit van een of ander kerkelijk of liefdadig initiatief. Zo zien we in 1323 een berouw hebbende koopman als penitentie op St Catherine's Point, de rotsachtige zuidpunt van het eiland Wight bij de Engelse Zuidkust, overgaan tot de stichting van een kapel, die hij met een dotatie begiftigde. Dit hield evenwel voor de priester, die er dienst zou doen, de verplichting in er 's nachts ten behoeve van de scheepvaart vóór de kust, lichten aan te steken. Aan deze dienstverlening kwam in 1530, met de Anglikaanse Reformatie, een einde ${ }^{261}$. Voordien reeds, in 1309 , had de prior van het klooster op Ecrehou, nabij het eiland Jersey, het meest zuidelijke van de Anglo-Normandische eilanden, er zich toe verbonden, opdat de zeevarenden in staat zouden wezen de gevaren van de nabijgelegen klippen te ontwijken, 's nachts in zijn kapel een "focum ardentem" of vuurhaard aan te leggen en gans het jaar in stand te houden ${ }^{262}$. Op te merken is, dat de

(259) Volgens een koninklijk privilegie verkregen in 1536 mocht Trinity House van Newcastle instaan voor de oprichting van vuurbakens langs de kust van Blyth tot Whitby. D. Jackson, Lighthouses of England and Wales. Londen, 1975, p. 11. Stevenson, p. 22.

(260) Tussen 1600 en 1690 werden de aldaar te Tynemouth, Spurn Point en Hunstanton aan de Wash reeds bestaande lichtbakens angevuld door die opgericht te Wintertonness, Winterton, Caister, Corton, Lowestoft, Orfordness, Harwich, North Foreland, South Foreland en Dungeness. Stevenson, p. 97 en vlg. met kaartje op p. 96.

(261) Ib., p. 22.

(262) „Et ipse, qui dicitur prior pro se et socio suo... et valetto eorum commorante in predicta capella per totum annum ad manutenendum... focum ardentem in capella illa ut marinelli mare transeuntes de nocte per focum illum... vitare possint pericula repellium capelle contiguarum...". De prior ontving in ruil een 
Engelse koningen, waarvan de heerschappij zich van 1154 tot 1453, ook over de streek van Bordeaux, de belangrijke haven van de Garonne aan de baai van de Gironde, d.i. in Guyenne, aan de Atlantische kust van Frankrijk, uitstrekte, zich aldaar met de veiligheid van de scheepvaart inlieten. Het was immers Edward, prins van Wales of de Zwarte Prins, die omstreeks 1370, tijdens zijn verblijf in dat gebied, tot de oprichting van een toren en een kapel op het met klippen en zandbanken omgeven eilandje Cordouan, gelegen ten westen van de inkom van de Gironde, overging. Dit geschiedde blijkbaar om een toen reeds lang bestaand baken, misschien tot de Karolingische tijd opklimmend, te vervangen. De dienstverlening op Cordouan ten behoeve van de zeelui en hun vaartuigen werd er immers van oudsher door een paar geestelijken, waaronder een eremijt, en in de 15 de eeuw voorgoed door twee eremijten verzekerd. Dezen mochten van de schippers, die van hun diensten gebruikt maakten, een bakenrecht eisen. Meer dan met een toorts of lichtende lantaarn zwaaien om, als het nodig was, de weg te wijzen, deden ze evenwel niet. Eerst in 1612, nadat Bordeaux al lang terug onder de heerschappij van de Franse monarchie gekomen was, werd op Cordouan de bekende vuurtoren, ontworpen door de ingenieur Louis de Fois, in gebruik genomen ${ }^{263}$.

Benoorden Cordouan, aan de Franse westkust tot Le Havre, bevonden er zich in de late middeleeuwen maar enkele vuurbakens van belang, namelijk dit op het eiland Oléron, dit van La Rochelle nabij het eiland Ré en dit van Guérande aan de Loiremonding. Tussen Le Havre en Bonen evenwel bestond toen al een kleine keten van zulke bakens. Inderdaad aldaar treffen we achtereenvolgens aan de „fouier” op de Chef-de-Caux aan de Seinemonding, opgericht in 1350, maar in 1517 vervangen door een nieuwe vuurtoren te Le Havre, de "fouier" van Fécamp, de twee "fouyers" van Dieppe, de „foier" van Berck en de „foyel" van Etaples. Deze laatste bestond nog in het begin van de $17 \mathrm{de}$ eeuw. Te Berck was de ,foier" een leen, behorende aan de stad ${ }^{264}$. Te Dieppe bevond de ene „fouyer", zijnde een stenen torentje, zich op de havenpier en de andere, die een havenlantaarn droeg, te Le Pollet, aan de haveninkom. Zowel te Etaples, als te Dieppe werd tot onderhoud van de vuren een "coustume du fouier" geheven ${ }^{265}$. De rij van deze Normandische en Pikardische vuurbakens sloot

jaarrente ten bedrage van 20 schellingen. Rolls of the Assizesi beld in the Channel Islands (1309). Uitgave van de Société Jersiaise. Jersey, 1903, p. 240.

(263) J. Bernard, Navires et gens de mer à Bordeaux (vers 1400-vers 1550). Reeks „Ports-Routes - Trafics”, Parijs, 1968, deel I, p. 92-95. - De La Roncière, dl. II, p. 538-539. - Stevenson, p. 21. - Het bakengeld, dat aanvankelijk 2 groten sterling per schip bedroeg, werd in 1409, krachtens een mandement van de Engelse koning, Hendrik IV, op 4 zulke groten gebracht. Na de herovering van het gebied door de Franse koning Karel VII, bedroeg het 6 schellingen tournoois. Th. Rymer, Foedera, conventiones, litterae etc inter reges Angliae et alios quosvis imperatores:, regis etc ab anno 1101 usque ad nostra tempora. Londen, 1704-1735, dl. IV, 1, p. 156. Tekst van het stuk van 8 aug. 1409 met verwijzing naar de Zwarte Prins inzake de oprichting van de nieuwe toren omstreeks 1370. - Paris, Bibliothèque Nationale, Français nr. 20855, p. 17. - Aan de oprichting van de toenmaals moderne vuurtoren op Cordouan werd van 1555 tot 1611 gewerkt.

(264) De la Roncière, dl. II, p. 542-543. - Dardel, p. 32.

(265) De beide vuurbakens worden eerst in 1396 vermeld. Abbé Cochet, Plan et 
oostwaarts, voorbij Bonen en Kales, bij de keten van de Vlaamse ,vierboetes" aan. Er kan dus zeker gesproken worden van het bestaan in de late middeleeuwen aan beide zijden van het Nauw van Kales en het nabijgelegen zuidwestelijk gedeelte van de Noordzee, in de driehoek Great Yarmouth, Chef-de-Caux en Brielle, van een weliswaar primitief, doch doelmatig nachtelijk signalisatiestelsel, waarvan de Vlaamse vuurbakens het voornaamste sluitstuk vormden. De variëteit in de middeleeuwse terminologie om de verschillende soorten vuurhaarden aan te duiden, namelijk "focus" of ,feux", „foier" of ,vierboete" doet daar niets van af, maar bewijst wel een gemeenschappelijke oorsprong, die voor het betrokken gebied typisch was: de ,vierberg" ${ }^{266}$. Voor de ontwikkeling van eenvoudige brandstapel op een hoogte, over vuur op een houten stelling tot stenen vuurtoren getuigt dan ook ongetwijfeld het best de Vlaamse ,vierboete".

description de la ville de Dieppe au XIVe siècle, d'après le coustumier ou cueilloir, recueilli par G. Tieullier. Dieppe, 1865, p. 21. - De ,garde et guete du fouyer, estans sur le Polet" wordt in 1420 met zijn naam vernoemd. Calendar of the Norman Rolls, 8 Henty V, pt II, m 27 dors. - M. Mollat, Le commerce maritime normand à la fin du moyen âge. Parijs 1952, p. 358, voetnoot 143. - Voor Fécamp, zie ibidem, p. 356.

(266) R.E. Latham, M.A., Revised medieval Latin word-list from British and Irish sources. Londen, 1965, verbis ",focus", ,ignis", „,pharus", "phararius" et „signum". We danken de "Medieval Latin Dictionary Committee", Public Record Office te Londen, in de persoon van haar ,assistant editor", miss Katherine Thomson, voor haar bereidwilligheid bij het bezorgen van de afschriften op "slips" van de passages uit de middeleeuwse bronnen, waarin de genoemde Latijnse termen voorkomen. 
CORRIGENDA EN AANVULLINGEN BIJ DEEL I, HMGOG, XXXVI, 1982

Blz. 41, voetnoot 10, lijnen 6 en $7:$ : Met de uitdrukking 'en vieulx temps' werd in de Oudheid blijkbaar herinnerd aan de Romeinse vuurtorens" moet zijn „Met de uitdrukking 'en vieulx temps' werd blijkbaar herinnerd aan de Romeinse vuurtorens in de Oudheid".

Blz. 44, voetnoot 19 : "Zie n. 174", moet zijn "Zie n. 170".

Blz. 51, tekst, lijn 27 : ,,was Karel de Grote. Dit gebeurde hoofdzakelijk om militaire redenen," moet zijn ,gaf Karel de Grote in 810 het bevel te Bonen een vloot samen te bren-".

Blz. 54, voetnoot 45, lijn 6: „Si cune” moet zijn "Si cume”.

Blz. 59 : tekst, lijn 5: "la chadelle" moet zijn „la chandelle”.

Bl\%. 64, illustratie, lijn 3 ; ,elk met hun 'vierboeter' " moet zijn ,elk met haar 'vierboeter'".

Blz. 68, tekst, lijn 22 : „zien we dat de Nieuwpoortse” moet zijn „,zien we de Nieuwpoortse".

Blz. 71, tekst, lijn 5: „evenals ene groot aantal” moet zijn ,evenals een groot aantal".

Blz. 77, tekst, lijn 5:,- misschien wel ten gevolge van nalatigheid vanwege de vier-" moet zijn ,en wel ten gevolge van nalatigheid van een militaire wacht en dus niet door de schuld van de vier-".

Blz. 78, tekst, lijn 4: "diende in 1613 wegens gevaar voor instorting" moet zijn "diende in 1613 wegens gevaar voor instorting van haar naald".

Blz. 78, voetnoot 126, lijn 7 : „Bamesse” moet zijn „kersmesse”.

Blz. 78, voetnoot 128, lijn 5: „1793" moet zijn ,1791".

Blz. 78, voetnoot 127, lijn 7 : „fort de Viervoetd" moet zijn „fort de Viervoete".

Blz. 79, voetnoot 129. Bij te voegen bibliografie: J. Beun, De vuurtoren van Nieuwpoort en zijn laatste "viertorrewachters", in Bachten de Kupe, dl. 23, jg. 1981, blz. 164-173. 
